\title{
Nature of crustal terranes and the Moho in northern Costa Rica from receiver function analysis
}

\section{Lepolt Linkimer and Susan L. Beck}

Department of Geosciences, University of Arizona, Gould-Simpson Building 77, Tucson, Arizona 85721, USA

(linkimer@email.arizona.edu)

Susan Y. Schwartz

Department of Earth and Planetary Sciences, University of California, Santa Cruz, California 95064, USA

\section{George Zandt}

Department of Geosciences, University of Arizona, Gould-Simpson Building 77, Tucson, Arizona 85721, USA

\section{Vadim Levin}

Department of Earth and Planetary Sciences, Rutgers University, Piscataway, New Jersey 08854, USA

[1] The Central American subduction zone in northern Costa Rica shows along-strike variations in both the incoming and overriding plates. By analyzing the subducting oceanic Moho (M1) and the upper plate Moho (M2) with receiver functions, we investigate the variability in the hydration state of the subducting Cocos Plate and the nature of crustal terranes within the overriding Caribbean Plate. We calculate high-quality $P$ and $P P$ wave receiver functions using broadband data of the Global Seismology Network; Geoscope Project; and the CRSEIZE, Pocosol, and Corisubmod experiments. In addition, we estimate the depth $(H)$ and vertically averaged $V p / V s(\kappa)$ to Moho and present a sensitivity study to explore the effects of a dipping interface on receiver functions and the $H$ and $\kappa$ estimates. Our results are consistent with a drier oceanic mantle subducting beneath the southernmost part of the Nicoya Peninsula, as compared to a serpentinized oceanic mantle subducting beneath the northern part. In the Caribbean Plate, we describe the nature of the Mesquito, Nicoya, and Chorotega terranes by integrating new and published $V p / V s$ estimates. Both the Nicoya and Chorotega terranes display high $V p / V s(1.80-1.92)$ consistent with their oceanic character. In contrast, the oceanic Mesquito Terrane mostly displays lower $V p / V s(1.62-1.80)$ more compatible with continental crust, which may indicate that subduction zone magmatism is modifying the crust to display continental character. Our estimates show that the deepest M2 $(\sim 42 \mathrm{~km})$ is observed in the volcanic arc region whereas the shallowest M2 $(\sim 27-33 \mathrm{~km})$ is observed in parts of the fore-arc and back-arc regions.

Components: 11,789 words, 13 figures, 1 table.

Keywords: Moho; terrane; $V p / V s$; receiver functions; Costa Rica.

Index Terms: 7240 Seismology: Subduction zones (1207, 1219, 1240); 8038 Structural Geology: Regional crustal structure; 8104 Tectonophysics: Continental margins: convergent.

Received 24 August 2009; Revised 12 November 2009; Accepted 19 November 2009; Published 27 January 2010. 
Linkimer, L., S. L. Beck, S. Y. Schwartz, G. Zandt, and V. Levin (2010), Nature of crustal terranes and the Moho in northern Costa Rica from receiver function analysis, Geochem. Geophys. Geosyst., 11, Q01S19, doi:10.1029/2009GC002795.

Theme: Central American Subduction System

Guest Editors: G. Alvarado, K. Hoernle, and E. Silver

\section{Introduction}

[2] The Central American subduction zone in Costa Rica shows along-strike variations that are useful for understanding subduction zone processes. In the incoming Cocos Plate, there is along-trench variability in the number and size of bathymetric features, outer rise fault patterns, and crustal age [e.g., von Huene et al., 2000; Barckhausen et al., 2001]. Outer rise faults are thought to create pathways for seawater to hydrate the uppermost mantle; therefore, heterogeneity in outer rise fault patterns may control the hydration and thermal state of the Cocos Plate segments [e.g., Ranero et al., 2005; Ivandic et al., 2008]. In northern Costa Rica, the trenchward location of the Nicoya Peninsula over the fore arc makes it ideal to study the hydration state of the subducting Cocos Plate using on-land geophysical experiments.

[3] In the upper plate, the modern volcanic arc is built upon the Chorotega and Chortis blocks. In Costa Rica, the Chortis Block consists of the oceanic Mesquito (or Siuna) Terrane [e.g., Rogers et al., 2007; Baumgartner et al., 2008]. In addition, the Nicoya Peninsula has been described as a separate Nicoya Terrane [Di Marco et al., 1995]. There is no consensus on the location of the boundary between these blocks and terranes (Figure 1). The Chorotega-Chortis boundary has been suggested to lie in southern Nicaragua [MacKenzie et al., 2008], along the Costa RicaNicaragua border [e.g., Dengo, 1985; Rogers et al., 2007], and near the Nicoya Gulf [Hauff et al., 2000], and has also been interpreted as a broad region, where both blocks coexist at depth, bounded to the south by the southwestward projection of the Hess Escarpment into central Costa Rica [Baumgartner et al., 2008].

[4] One of the intriguing aspects of the crust in northern Costa Rica is that it displays a continental character even though it is presumably composed of terranes of oceanic origin. There are largevolume silicic pyroclastic flows and ignimbrites associated with the volcanic arc [Vogel et al., 2004, 2006] and the velocity structure and crustal thickness have been suggested as indicators of continental crust [e.g., Drummond et al., 1995; Sallarès et al., 2001; Vogel et al., 2004; MacKenzie et al., 2008].

[5] Costa Rica has been the site of numerous geological and geophysical studies and much progress has been made toward understanding the lithospheric structure and tectonics [e.g., Sallarès et al., 2001; DeShon et al., 2006; MacKenzie et al., 2008; Baumgartner et al., 2008]. In this study, we build upon previous work and analyze a larger data set of receiver functions at stations in northern Costa Rica. The main goals of this paper are to describe the amplitude and azimuthal variation of converted waves from both the subducting oceanic Moho (M1) and the upper plate Moho (M2) and to calculate the depth $(H)$ and vertically averaged $\mathrm{Vp} /$ $V s(\kappa)$ to these interfaces. Our intention is to use this information to investigate the variation in the hydration state of the subducting Cocos Plate. By integrating our new receiver function estimates with published geological data and the receiver function estimates from MacKenzie et al. [2008], we describe the nature of crustal blocks and terranes (Mesquito, Nicoya, and Chorotega) within the overriding Caribbean Plate and reexamine the previously proposed boundaries between them.

[6] We present evidence of a drier oceanic mantle subducting beneath the southernmost part of the Nicoya Peninsula, as compared to a serpentinized oceanic mantle subducting beneath the central and northern parts. We also document a moderate to low $V p / V s$ in the fore arc and volcanic arc of northern Costa Rica similar to the $V p / V s$ of continental crust regions. In addition, by computing synthetic receiver functions for simple velocity models, we examine the bias that might be introduced in the $H$ and $\kappa$ estimates by a dipping interface and study the azimuthal variation in $P$ to $S$ wave conversions $(P S)$ and reverberations 


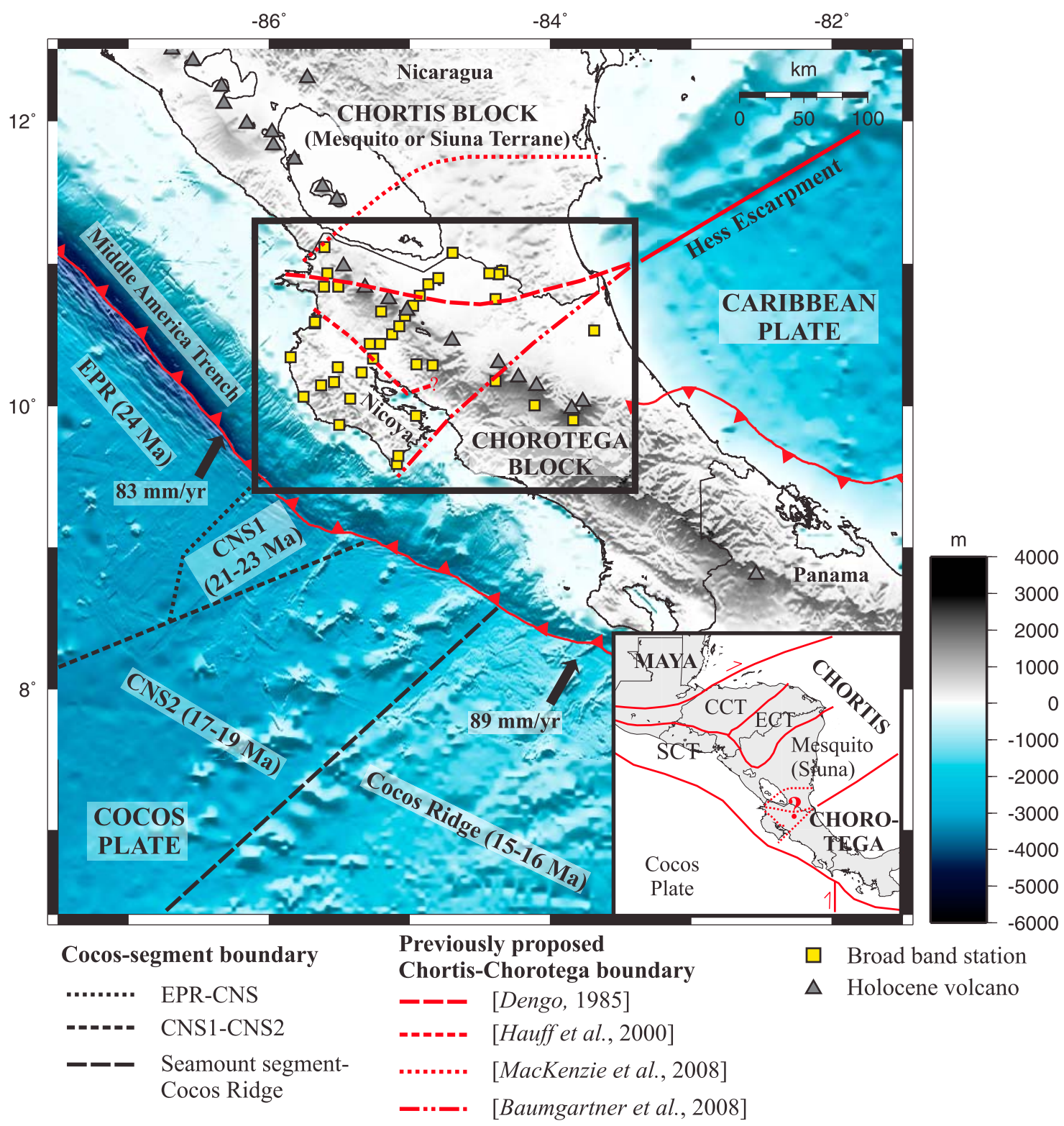

Figure 1. Major tectonic features of southern Central America. The age of the Cocos Plate shown in parentheses corresponds to the age at the trench axis [Barckhausen et al., 2001]. Velocity plate vectors come from DeMets et al. [1994], and bathymetry is from Ranero et al. [2005] and is available through the Marine Geoscience Data System. Rectangle denotes close-up region shown in Figure 2. Inset map of Central America shows regional terrane boundaries based on Rogers et al. [2007] and Baumgartner et al. [2008]. CCT, Central Chortis Terrane; CNS, Cocos Nazca Spreading Center; ECT, Eastern Chortis Terrane; EPR, East Pacific Rise; SCT, Southern Chortis Terrane.

expected above the subducting Cocos Plate in the Nicoya Peninsula.

\section{Tectonic Framework}

[7] Central America has been traditionally divided into two main tectonic blocks (Figure 1). The Chortis Block, to the north, is mostly underlain by Paleozoic continental basement and/or accreted oceanic rocks [Rogers et al., 2007]. The Chorotega Block, to the south, has no crystalline Paleozoic basement but instead consists of a $\sim 20 \mathrm{~km}$ thick oceanic plateau known as the Caribbean Large Igneous Province (CLIP), which formed $\sim 88-$ $91 \mathrm{Ma}$ during a period of extreme volcanism related to the initiation of the Galapagos hot spot [Sinton et al., 1998; Hauff et al., 2000]. 


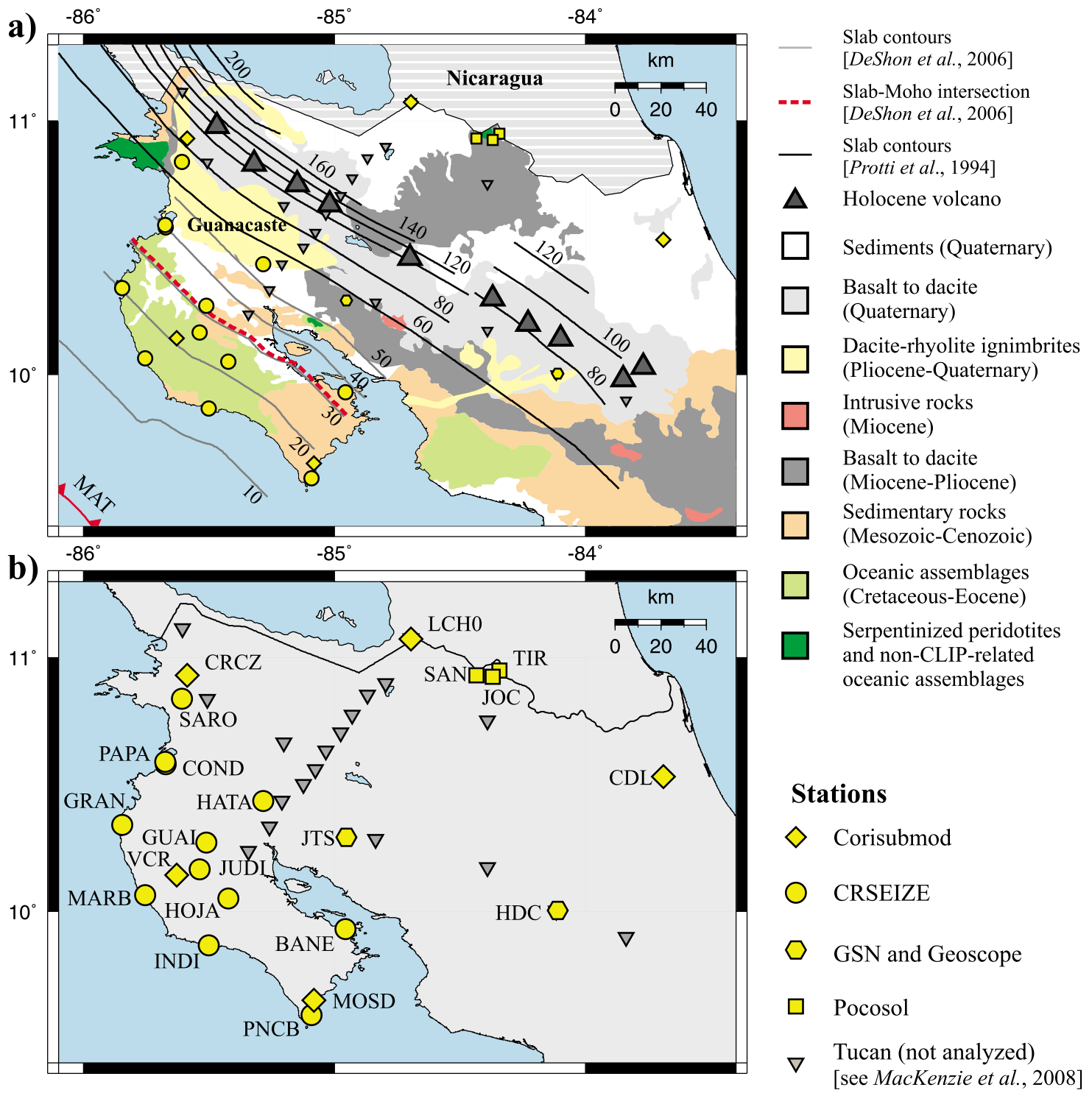

Figure 2. (a) Simplified geologic map of northern Costa Rica [Denyer et al., 2003; Vogel et al., 2004] and contours of the top of the slab (in km). MAT, Middle America Trench. (b) Location of recent broadband deployments in northern Costa Rica. Yellow symbols represent stations analyzed in this study.

[8] The Chortis Block has been traditionally described as continental [e.g., Dengo, 1985]. However, recent studies have described it as composed of terranes of both oceanic and continental origins [Rogers et al., 2007]. The Central Chortis Terrane, largely restricted to Honduras, is strictly continental (Figure 1). But, the southernmost part of the Chortis Block, known as Siuna Terrane in Nicaragua [Rogers et al., 2007], or Mesquito Oceanic Composite Terrane from El Salvador to northern Costa Rica [Baumgartner et al., 2008], includes deformed rocks of both Ocean Island Basalt (OIB) and island arc affinities that were accreted to the edges of the Central and Eastern Chortis Terranes during Late Cretaceous [Rogers et al., 2007; Baumgartner et al., 2008].

[9] The Nicoya Peninsula has been described as a separate Nicoya Terrane [Di Marco et al., 1995], where the Nicoya Complex is exposed (Figure 2a). The Nicoya Complex represents a set of Cretaceous plateaus that intruded Jurassic-Early Cretaceous radiolarites between 139 and $83 \mathrm{Ma}$ and has been interpreted as fragments of the CLIP [Denyer and Gazel, 2009, and references therein] as well as Pacific pre-CLIP plateaus [Baumgartner et al., 2008]. Along the Pacific coast, to the south of the Nicoya Peninsula, there are exposures of younger (Late Cretaceous to Tertiary) igneous com- 
plexes that consist of portions of seamounts and aseismic ridges uplifted and/or accreted to the margin but are related to the activity of the Galapagos hot spot after the formation of the CLIP [Hoernle et al., 2002].

[10] Costa Rica is located at the southern end of the Middle America Trench (MAT) in a tectonic setting controlled by the interaction of the Cocos, Caribbean, and Nazca plates. The Cocos Plate is subducting to the northeast underneath the Caribbean Plate at a rate of $\sim 83 \mathrm{~mm} / \mathrm{yr}$ in northwestern Costa Rica [DeMets et al., 1994]. The volcanic arc is located $\sim 150 \mathrm{~km}$ to the northeast of the MAT. Extensive silicic magmatism, dominated by rhyolitic ignimbrites, has occurred in the central and northern parts of Costa Rica between $\sim 6$ and $0.32 \mathrm{Ma}$. The ignimbrite deposits in the Guanacaste region (Figure 2a) represent the most voluminous $\left(>200 \mathrm{~km}^{3}\right)$ silicic volcanic deposits in Costa Rica [Vogel et al., 2004].

[11] In the incoming Cocos Plate, off the coast of the Nicoya Peninsula, two different segments have been identified (Figure 1). The northern segment is characterized by a $\sim 5 \mathrm{~km}$ thick oceanic crust [e.g., Grevemeyer et al., 2007] that was created at the East Pacific Rise (EPR). The oceanic crust is 24 Ma [Barckhausen et al., 2001] at the trench, has exceptionally low heat flow $\left(\sim 14 \mathrm{~mW} / \mathrm{m}^{2}\right.$ [Langseth and Silver, 1996]), and displays pervasive normal faulting that presumably extends through the entire oceanic crust and facilitates the hydration of the uppermost mantle [Ranero et al., 2003]. Furthermore, the oceanic mantle rocks show anomalously low $P$ wave velocities in tomographic images, suggesting $12 \%-17 \%$ serpentinization [Ivandic et al., 2008]. The segment located off the coast of southern Nicoya is characterized by $\sim 7 \mathrm{~km}$ thick oceanic crust created at an ancient CocosNazca Spreading Center (CNS1), has relatively high heat flow $\left(\sim 110 \mathrm{~mW} / \mathrm{m}^{2}\right)$, displays only a few small-offset faults in the outer rise, and exhibits age variability along the margin, from 21 to $23 \mathrm{Ma}$ [von Huene et al., 2000; Barckhausen et al., 2001; Ranero et al., 2003].

\section{Previous Geophysical Studies}

[12] A simplified picture of the margin in northern Costa Rica has been constructed from local tomography [e.g., Sallarès et al., 2000; Husen et al., 2003; DeShon et al., 2006; Syracuse et al., 2008], receiver functions [DeShon and Schwartz, 2004; MacKenzie et al., 2008], and reflection and refrac- tion studies [e.g., Ye et al., 1996; Christeson et al., 1999; Sallarès et al., 1999, 2001; Bullock et al., 2007; Grevemeyer et al., 2007]. The upper plate has been divided into three levels tied to velocity gradients instead of first-order velocity contrasts [Sallarès et al., 2001]. The margin wedge has been imaged as a region of high velocities compared to those expected for an accretionary prism and has been interpreted as the seaward extension of the Nicoya Complex [e.g., Ye et al., 1996; Christeson et al., 1999]. The uppermost mantle beneath the fore arc displays reduced velocities $(6.8-7.2 \mathrm{~km} / \mathrm{s})$ and has been interpreted as evidence for $15 \%-25 \%$ serpentinization [Sallarès et al., 2001; DeShon and Schwartz, 2004; DeShon et al., 2006].

[13] The upper plate Moho (M2) has been identified at a depth range of 27 to $43 \mathrm{~km}$, based on $P n$ and $P g$ travel times [Matumoto et al., 1977; Quintero and Kulhánek, 1998], seismic refraction [Sallarès et al., 1999, 2001], and receiver functions [DeShon and Schwartz, 2004; MacKenzie et al., 2008]. M2 has been imaged as a region of lowvelocity contrast in the fore arc [DeShon et al., 2006; Arroyo et al., 2009] and interpreted as a transition zone [Sallarès et al., 2001]. Using receiver functions, which are sensitive to discontinuities, MacKenzie et al. [2008] were able to image $\mathrm{M} 2$ as a relatively strong velocity contrast $(\sim 0.5-$ $1.0 \mathrm{~km} / \mathrm{s}$ ) beneath both the volcanic arc and backarc regions and describe a more complicated signal in the fore-arc region. The intersection of the subducting Cocos Plate with M2 (Figure 2a) occurs at depths of 30-34 km beneath the western part of the Nicoya Peninsula [Sallarès et al., 1999; DeShon et al., 2006].

[14] The subducting Cocos Plate has been recognized from Wadati-Benioff Zone (WBZ) seismicity [e.g., Protti et al., 1994; Newman et al., 2002; DeShon et al., 2006], seismic refraction [e.g., Christeson et al., 1999; Sallarès et al., 2001], and seismic tomography [e.g., Husen et al., 2003; DeShon et al., 2006; Syracuse et al., 2008], but has not been previously imaged using receiver functions. A narrow zone of low velocities paralleling the top of the high-velocity subducting Cocos Plate was recognized by Husen et al. [2003] and linked to a cold and highly hydrated Cocos oceanic crust that is subducting beneath northern Costa Rica.

\section{Data and Methodology}

[15] Receiver function analysis is a method used to provide constraints on lithospheric structure by 
a)
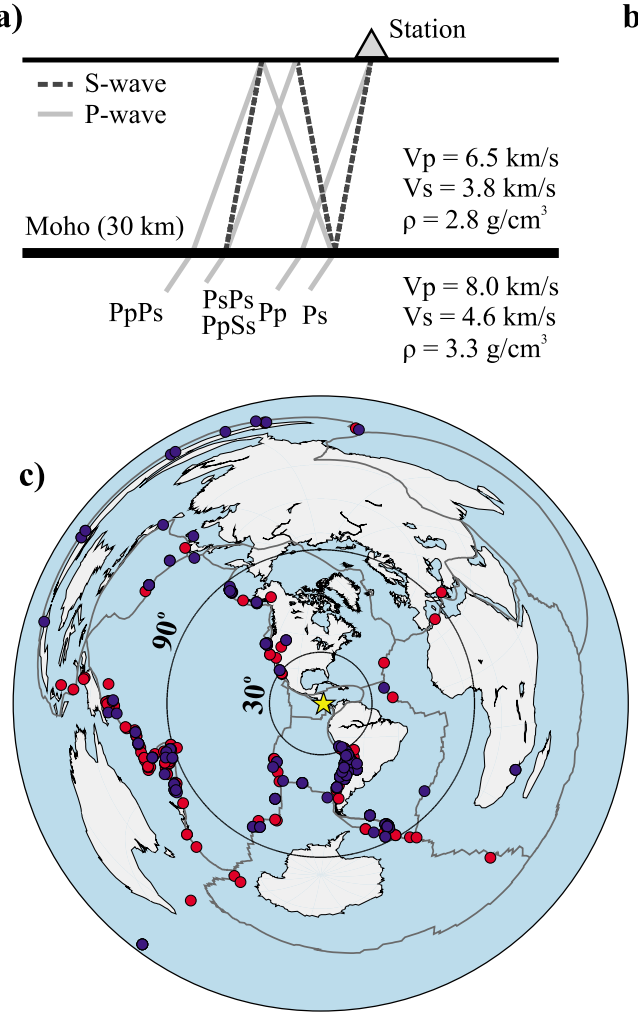

b)

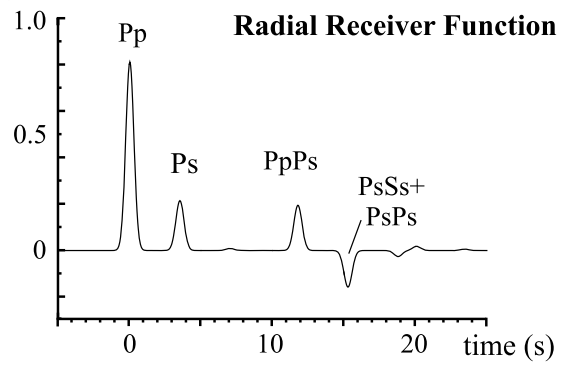

\section{Earthquake recorded at}

- GSN and Geoscope

- CRSEIZE, Pocosol, and Corisubmod
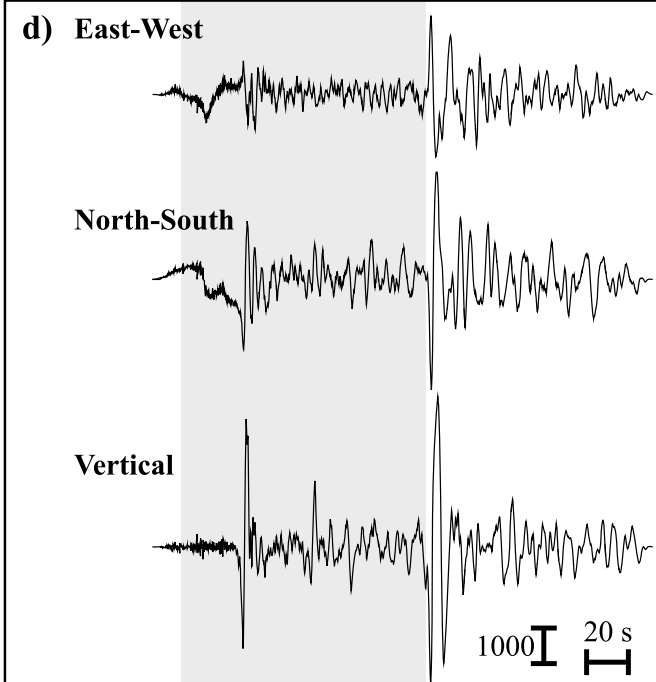

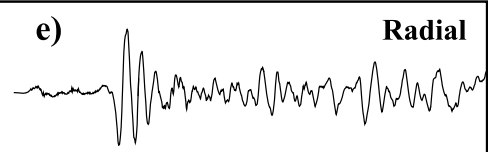

dial

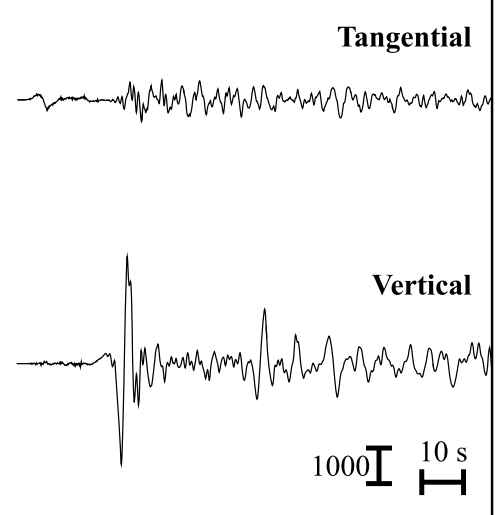

Figure 3. (a) Raypath geometry and nomenclature of $P$ to $S$ converted waves recorded in receiver functions for a model of a layer over a half-space with a flat Moho and (b) synthetic radial receiver function response. (c) Epicenter distribution of teleseismic earthquakes used. Yellow star denotes the location of Costa Rica. (d) Example of a threecomponent seismogram recorded at station JOC. The window used for the receiver function calculation is shaded in gray and shown as (e) the band-pass-filtered signal $(0.1-3 \mathrm{~Hz})$ after the horizontal components were rotated.

isolating $P s$ and its multiples (i.e., $P p P s, P s P s$, and $P p S s$, Figures $3 \mathrm{a}$ and $3 \mathrm{~b}$ ) produced at interfaces beneath a three-component receiver. This is accomplished by deconvolving the vertical $P$ wave energy from the horizontal components under the assumption that very little converted energy appears on the vertical component for steeply incident rays (distances $>30^{\circ}$ ). The deconvolution procedure removes both source effects and instrument response, resulting in a time series that is sensitive only to the lithospheric interfaces beneath the seismic station where Ps occur [Langston, 
Table 1. Results by Individual Station

\begin{tabular}{|c|c|c|c|c|c|c|c|c|}
\hline Station & Latitude & Longitude & $\mathrm{Vp}^{\mathrm{a}}$ & $\mathrm{N}^{\mathrm{b}}$ & Depth to $M 1^{\mathrm{c}}$ & Depth to $M 2^{\mathrm{c}}$ & $V p / V s$ to $\mathrm{M} 1^{\mathrm{c}}$ & $V p / V s$ to $\mathrm{M} 2^{\mathrm{c}}$ \\
\hline GRAN & 10.340 & -85.846 & 6.0 & 14 & $26.8 \pm 1.9^{\mathrm{d}}$ & - & $1.84 \pm 0.06^{\mathrm{d}}$ & - \\
\hline HDC & 10.002 & -84.112 & 6.3 & 85 & - & $41.7 \pm 2.3$ & - & $1.92 \pm 0.05$ \\
\hline INDI & 9.865 & -85.502 & 6.0 & 10 & $21.8 \pm 1.7^{\mathrm{d}}$ & - & $1.87 \pm 0.05^{\mathrm{d}}$ & - \\
\hline JOC-TIR & 10.925 & -83.370 & 6.3 & 46 & - & $28.7 \pm 1.4$ & - & $1.85 \pm 0.06$ \\
\hline JTS & 10.291 & -84.952 & 6.5 & 111 & - & $36.7 \pm 2.4$ & - & $1.69 \pm 0.05$ \\
\hline MARB & 10.063 & -85.754 & 6.0 & 27 & $23.8 \pm 1.3^{\mathrm{d}}$ & - & $1.80 \pm 0.05^{\mathrm{d}}$ & - \\
\hline MOSD-PNCB & 9.647 & -85.083 & 6.0 & 26 & $24.8 \pm 2.3^{\mathrm{d}}$ & - & $1.83 \pm 0.06^{\mathrm{d}}$ & - \\
\hline PAPA-COND & 10.590 & -85.677 & 6.0 & 30 & - & $27.1 \pm 2.0$ & - & $1.62 \pm 0.09$ \\
\hline SARO & 10.839 & -85.609 & 6.3 & 9 & - & $32.9 \pm 1.1$ & - & $1.65 \pm 0.03$ \\
\hline
\end{tabular}

${ }^{\text {a }}$ Based on previous studies (see references in section 4.2).

${ }^{\mathrm{b}}$ Number of receiver functions with variance reduction $>80 \%$.

${ }^{\mathrm{c}}$ Depth in $\mathrm{km}$. M1, oceanic Moho; M2, upper plate Moho. The uncertainty range is estimated as presented by Zhu and Kanamori [2000].

${ }^{\mathrm{d}}$ A poststack correction was applied as described in section 5.2.

1979]. In this study, receiver functions were calculated by applying an iterative time domain deconvolution approach. This estimation is a least squares minimization of the difference between the observed horizontal seismogram and a predicted signal generated by the convolution of an iteratively updated spike train with the vertical component seismogram [Ligoría and Ammon, 1999].

[16] $P$ and $P P$ wave receiver functions were calculated using teleseismic events recorded by stations of the CRSEIZE Experiment from December 1999 to December 2001, Pocosol Network from April 2005 to July 2006, and Corisubmod Project from February 2005 to February 2007, as well as Geoscope Project station HDC from March 1997 to December 2005 and Global Seismology Network station JTS from April 1995 to May 2008 (Figure 2b). The majority of these stations were equipped with Streckeisen STS-2, Guralp CMG3T and 40T, and Trillium seismometers.

[17] We calculated a total of 615 high-quality receiver functions from 22 broadband stations. The number of events for individual stations varies from 1 to 111, depending on the length and quality of recording. Stations HDC and JTS have the largest number of high-quality receiver functions documented for a single station in Costa Rica, with 85 and 111, respectively. We do not show results for stations with less than nine high-quality receiver functions (CRCZ, HOJA, VCR, and LCHO) and stations HATA, CDL, and SAN, where shallow structures and/or sedimentary basin reverberations precluded interpretation. In order to increase the number of traces and improve the signal-to-noise ratio, stations close to each other were stacked, such as PAPA and COND, PNCB and MOSD, and JOC and TIR (Table 1 and Figure 2b).
[18] Earthquake locations were selected from the U.S. Geological Survey National Earthquake Information Center (NEIC) with magnitude $>5.5$ and a distance range from $30^{\circ}$ to $90^{\circ}$ for calculating $P$ wave receiver functions and with magnitude $>6.0$ from $90^{\circ}$ and $180^{\circ}$ for calculating $P P$ wave receiver functions. Our data are mostly composed of events clustered in back azimuths of $140-340^{\circ}$, especially from South America and the South Pacific regions (Figure 3c).

\subsection{Data Processing}

[19] Each earthquake recorded on the Z, E-W, and $\mathrm{N}-\mathrm{S}$ components was band-pass-filtered $(0.1-3 \mathrm{~Hz}$ and $0.2-3 \mathrm{~Hz}$ ) and the horizontal components were rotated to the radial and tangential directions of the great circle path, based on the NEIC hypocentral locations. For the receiver function calculation we applied an iterative time domain deconvolution approach [Ligoría and Ammon, 1999] on a time window of $120 \mathrm{~s}$ for each record, starting $20 \mathrm{~s}$ before $P$ or $P P$ wave onset (Figures $3 \mathrm{~d}$ and $3 \mathrm{e}$ ) and applied Gaussian filter width factors of 1.0 and 2.5 to remove high-frequency noise [e.g., Cassidy, 1992].

[20] For each event-station pair, we examined four different receiver functions using a combination of the aforementioned band-pass and Gaussian filters, and selected the combination with the best signalto-noise ratio. For stations in the Nicoya Peninsula, a band-pass filter of $0.2-3 \mathrm{~Hz}$ and a Gaussian of 2.5 was preferred. For the remaining stations, we used a band-pass filter of $0.1-3 \mathrm{~Hz}$ and a Gaussian of 2.5. Also, both absolute amplitude and normalized to the maximum amplitude receiver functions were calculated for the above combination of parameters. To analyze the highest-quality results, we rejected events with less than $80 \%$ match 
between the predicted and observed waveforms produced via a comparison of the radial (or tangential) component seismogram with a convolution of the vertical component seismogram and the receiver function (i.e., variance reduction less than $80 \%$ ).

\subsection{Depth and $V p / V s$ Calculations}

[21] The depth $(H)$ and vertically averaged $V p / V s$ $(\kappa)$ estimates to Moho were obtained using a stacking algorithm that maps in the $H-\kappa$ domain the weighted sum of the radial receiver function amplitudes of each phase [ $\mathrm{Zhu}$ and Kanamori, 2000]. The radial receiver function stack $s(H, \kappa)$ is given by the equation:

$s(H, \kappa)=\omega_{P S} r\left(t_{P S}\right)+\omega_{P p P s} r\left(t_{P p P S}\right)-\omega_{P p S s+P s P s} r\left(t_{P p S s+P_{s} P_{s}}\right)$

where $\omega$ is the weight associated with the radial receiver function $\mathrm{r}(\mathrm{t})$ of the $P s, P p P s$, and $P p S s+$ $P s P s$ phases (Figures $3 \mathrm{a}$ and $3 \mathrm{~b}$ ). The arrival times $\left(t_{\mathrm{Ps}}, t_{\mathrm{PpPs}}\right.$, and $\left.\mathrm{t}_{\mathrm{PpSs}+\mathrm{PsPs}}\right)$ are predicted from the ray parameter (p) and the depth and velocity structure to Moho. During stacking, $\omega$ is assigned to each of the three phases such that the sum of $\omega$ equals 1.0. We tested several weighting schemes but we present the results obtained from one that gives equal weight to the three phases $\left(\omega_{\mathrm{Ps}}=1 / 3 \omega_{\mathrm{PpPs}}=\right.$ $\left.1 / 3 \omega_{\text {PpSs }+ \text { PsPs }}=1 / 3\right)$ to ensure equal importance to each phase independent of their actual amplitude.

[22] Receiver functions were stacked for depth and $V p / V s$ ranges from 10 to $70 \mathrm{~km}$ and 1.6 to 2.1 , respectively. A point of maximum amplitude or "bull's eye" occurs when the three phases are stacked coherently and it denotes the most likely solution for $H$ and $\kappa$. In order to constrain the confidence in our results, we estimated uncertainties based on the variance of the $s(H, \kappa)$ stack and the flatness at the maximum, as proposed by $Z h u$ and Kanamori [2000].

[23] Since the time delay equations for $P S$ and multiples hold for flat interfaces, we estimated $H$ and $\kappa$ to Moho using this algorithm only at stations where the receiver function azimuthal behavior suggests flat layers. For the dipping Cocos Plate, $H$ and $\kappa$ were approximated by applying a poststack correction to $H$ and $\kappa$ based on synthetic data (see section 5.2).

[24] Receiver functions were stacked assuming that a standard $V p$ represents a reasonable average crustal wave speed (Table 1). A crustal $V p$ of either 6.0 or $6.3 \mathrm{~km} / \mathrm{s}$ was used for stations in the Nicoya region based on DeShon and Schwartz [2004]. A higher $V p$ of $6.3 \mathrm{~km} / \mathrm{s}$ and $6.5 \mathrm{~km} / \mathrm{s}$ was used for JTS and Pocosol stations, respectively, based on Sallarès et al. [2001]. For stations LCH0 and HDC we used a $V p$ of 6.0 and $6.3 \mathrm{~km} / \mathrm{s}$, respectively, based on Syracuse et al. [2008]. We do not expect deviations from the assumed $V p$ to significantly affect our results (see section 5.3).

[25] To discriminate between $P s$ and multiples $(P p P s$, and $P p S s+P s P s)$ we plotted the moveout of phase arrivals as a function of ray parameter. $P S$ arrivals exhibit positive moveout with respect to the direct $P$ wave arrival with increasing ray parameter, while the ray geometry of multiples produces a negative moveout. Thus, we compare expected and observed moveout on receiver functions in order to verify that the arrival of $P s$ phases and multiple reverberations are produced at particular depths.

\section{Sensitivity Tests}

[26] By knowing the dip direction $\left(\sim \mathrm{N} 40^{\circ} \mathrm{E}\right)$ and dip angle $\left(\sim 13-35^{\circ}\right)$ of the subducting Cocos Plate beneath the Nicoya Peninsula [DeMets et al., 1994; Christeson et al., 1999; Sallarès et al., 2001], we examined the receiver function sensitivity to a dipping interface as a function of back azimuth and amount of dip, as well as the assumed $V p$. This analysis was performed by calculating synthetic receiver functions with no noise. Synthetic seismograms were generated using RAY3D [Owens, 1984], a 3-D ray tracing code based on Langston [1977]. The $P$ and $S$ wave velocities, density, strike, dip angle, and thickness were specified for each layer in the model. Synthetic vertical, radial, and tangential seismograms were generated by specifying a back azimuth and ray parameter for an incident $P$ wave at the base of the model. Synthetic receiver functions were computed by applying the deconvolution procedure (section 4.1) on the synthetic responses.

\subsection{Sensitivity to Back Azimuth}

[27] In the presence of a dipping interface, stacking to create an average receiver function risks misinterpretation of the structure as $P S$ and multiples may show a strong azimuthal variation in timing, amplitude, and polarity [e.g., Cassidy, 1992; Hayes and Furlong, 2007] (Figure 4). We analyzed the azimuthal behavior of synthetic receiver functions to search for the direction at which the complications are minimized. We performed this analysis by creating synthetic receiver functions using a dip- 
a)
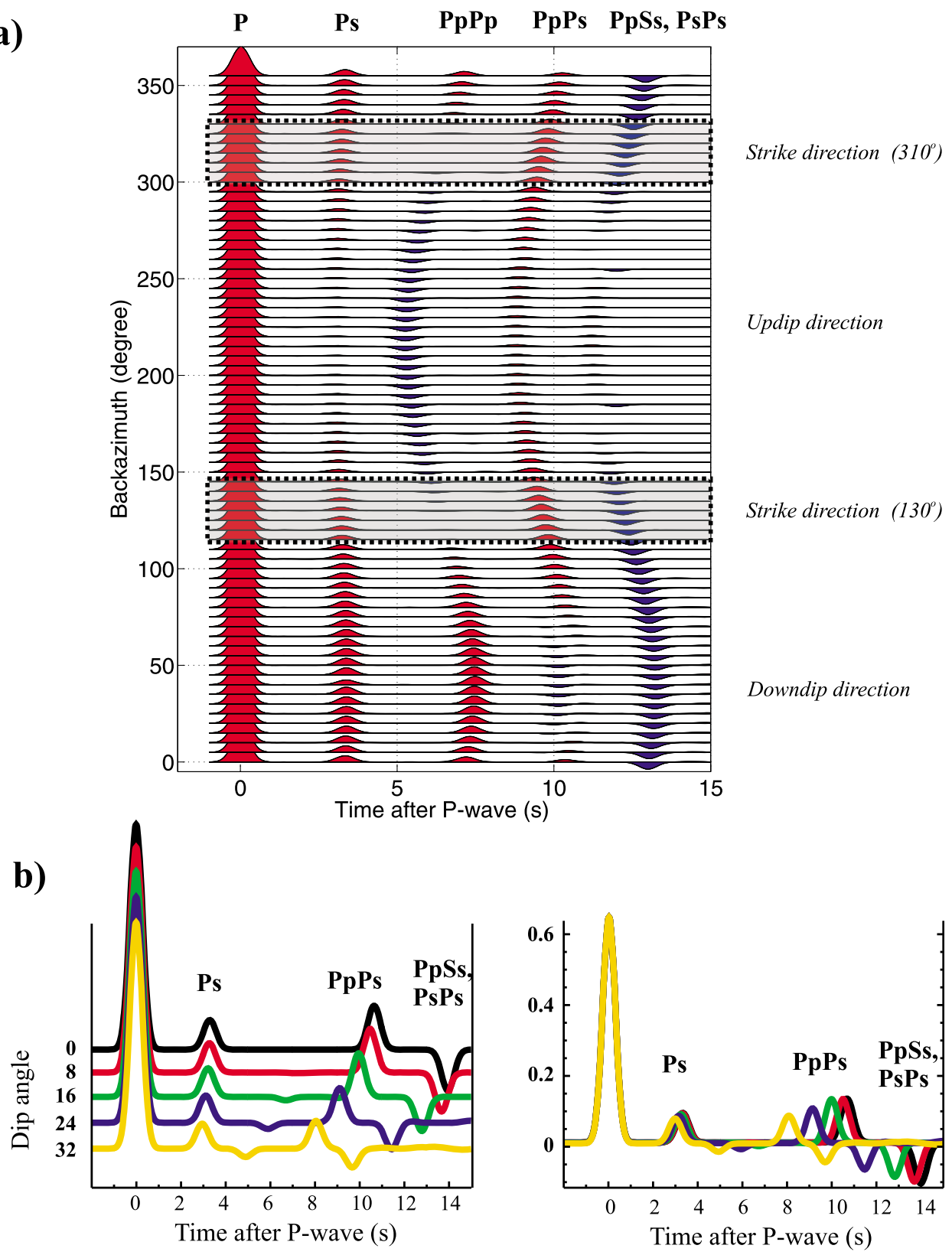

Figure 4. (a) Azimuthal variation of the radial component of synthetic receiver functions for a model of a dipping layer over a half-space. The model has an interface at $25 \mathrm{~km}$ depth, dipping $20^{\circ}$ toward $\mathrm{N} 40^{\circ} \mathrm{E}$. We used $V p=6.3 \mathrm{~km} /$ $\mathrm{s}, \mathrm{Vp} / \mathrm{Vs}$ of 1.80 , and a constant ray parameter of 0.06 . Note the absence of the $P p P p$ phase (shaded region) along the strike of the dipping interface. (b) Along-strike receiver functions for the same velocity model in Figure 4a but varying dip angle. Note that the $P s$ amplitude is not very sensitive to the dip angle.

ping interface with the appropriate orientation for our study region. We found that receiver functions along the strike of the dipping interface are similar to a flat interface case, particularly for the $P s$ phase and the absence of $P p P p$ phases that are observed at other back azimuths (Figure $4 \mathrm{a}$ ). In addition, the $P s$ amplitude of receiver functions along the strike is not very sensitive to changes in the dip angle (Figure 4b). These observations motivated us to stack our observed receiver functions along the strike of the subducting Cocos Plate for individual stations located in the Nicoya Peninsula, in order to compare the Ps amplitude between stations.

\section{2. $H-\kappa$ Sensitivity to Dip Angle}

[28] Rossi et al. [2006] and Hayes and Furlong [2007] developed a new method to estimate depth and $V p / V s$ to dipping interfaces by stacking receiver 

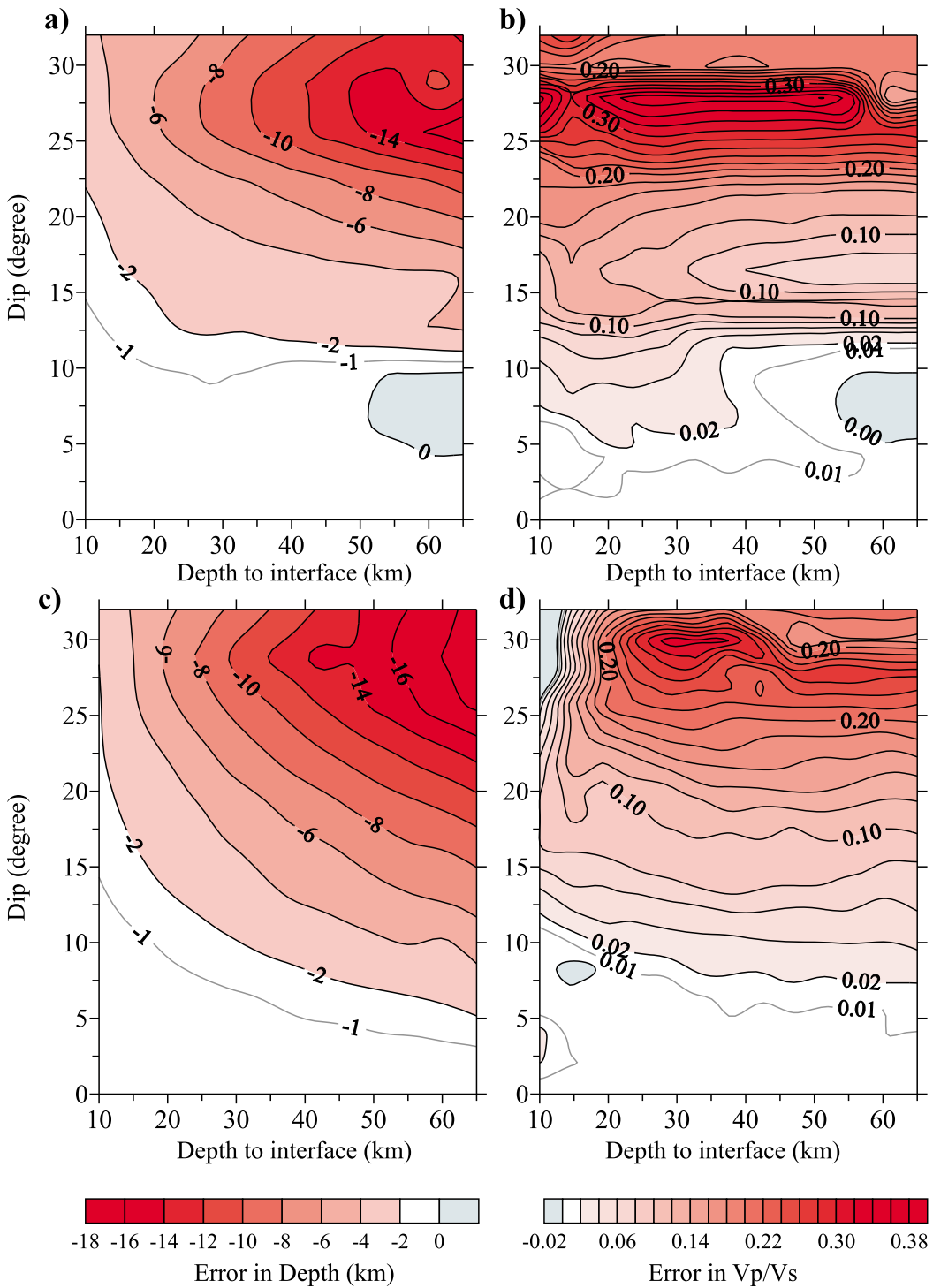

Figure 5. Bias in (a) interface depth and (b) $V p / V s$ estimate from $H-\kappa$ analysis for models with varying interface depth and dip angle. The contour map is based on synthetic receiver functions created using a model that intends to represent the subducting Cocos Plate dipping towards the northeast, beneath a mafic crustal wedge with $V p=6.3 \mathrm{~km} / \mathrm{s}$ and $V p / V s$ of 1.80. (c and d) Same as Figures $5 \mathrm{a}$ and $5 \mathrm{~b}$ but using synthetics computed with the azimuthal coverage and ray parameters of our data set. Contours were constructed using a method of triangulation with linear interpolation.

functions. We chose to use an alternative approach to this problem by investigating the potential bias introduced by a dipping interface in the $H-\kappa$ stacking algorithm, similar to that presented by Lombardi et al. [2008] for the Alps. We stacked synthetic receiver functions calculated from models with varying interface depth and dip angle and created a map of the differences between the apparent results for $H$ and $\kappa$ and the true model values which are referred hereafter as "bias in depth" and "bias in $V p / V s$. ." The biases given in Figures $5 \mathrm{a}$ and $5 \mathrm{~b}$ are representative of receiver functions from all back azimuths and ray parameter of 0.06 whereas those in Figures $5 \mathrm{c}$ and $5 \mathrm{~d}$ are representative of the ray parameter and azimuthal coverage of our data set.

[29] We found that when dealing with a dipping interface, calculations are biased toward shallower depths and higher $V p / V_{s}$ than true model parameters. In the case of a full and evenly distributed azimuthal coverage (Figures 5a and 5b), the depth bias is small $(<1 \mathrm{~km})$ for an interface dipping $<12^{\circ}$. The bias in the $V p / V s$ estimate could be as high as 0.08 for a 10 to $40 \mathrm{~km}$ depth interface dipping $12^{\circ}$. If the interface depth varies from $40 \mathrm{~km}$ to $60 \mathrm{~km}$ 
a)

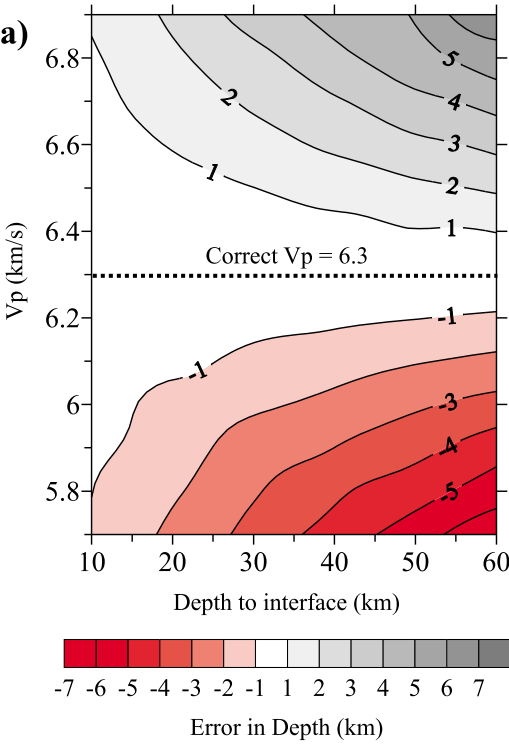

b)

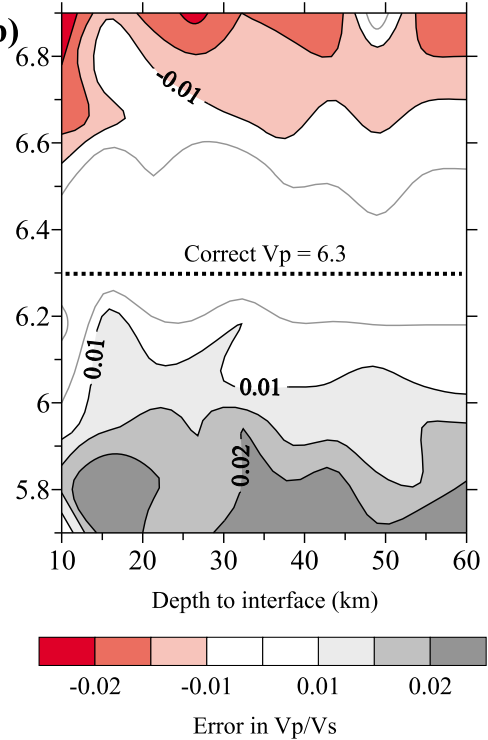

Figure 6. Bias in (a) interface depth and (b) $V p / V s$ estimated from $H-\kappa$ analysis for models with varying interface depth and $V p(V p=6.3 \mathrm{~km} / \mathrm{s}$ is the correct model value). The map of the bias is based on synthetic receiver functions with a symmetric azimuthal coverage every $5^{\circ}$ and a constant ray parameter of 0.06 . We used $V p / V s$ of 1.80 for a model of a flat layer over a half-space. Contours were constructed using a method of triangulation with linear interpolation.

and the interface dips $<12^{\circ}$, the $V p / V s$ bias is $<0.02$. We recommend using the $H-\kappa$ stacking algorithm with caution when the dip angle is known to be greater than $12^{\circ}$, as the bias in $\mathrm{Vp} /$ $V s$ could be geologically significant, especially if the interface depth is $>35 \mathrm{~km}$.

[30] Beneath the Nicoya Peninsula, the depth to the top of the $\sim 7 \mathrm{~km}$ thick Cocos crust varies from 15 to $35 \mathrm{~km}$ [DeShon et al., 2006] and its dip angle is $13^{\circ}$ beneath the coastline [Christeson et al., 1999; Sallarès et al., 1999, 2001]. For the ray parameter and azimuthal coverage of our data set (Figures 5c and 5d) and within the $10-35 \mathrm{~km}$ depth range, the bias is likely to be $<4 \mathrm{~km}$ in depth and $<0.08$ in $\mathrm{Vp} /$ $V s$ for an interface dipping $<14^{\circ}$. For a $13^{\circ}$ dipping oceanic Moho at $22 \mathrm{~km}$ depth, as expected beneath the coastline in central Nicoya [Christeson et al., 1999], the bias is on the order of $2 \mathrm{~km}$ in depth and -0.05 in $V p / V s$. We used these values as a correction that we applied to our $H$ and $\kappa$ estimates for the coastal stations INDI, MARB, and PNCB. Similarly, we applied a correction for station GRAN (3 km and -0.09).

[31] For stations BANE, GUAI, and JUDI the expected M1 depth and dip angle may be $>30 \mathrm{~km}$ and $>30^{\circ}$, respectively. Even though our calculations suggest that $V p / V s$ is higher than 1.80 for these sites, we think the $H-\kappa$ stacking algorithm should not be used as biases predicted from synthetic data are too large ( $>8 \mathrm{~km}$ in depth and $<-0.20$ in $\mathrm{Vp} / \mathrm{Vs})$. Similarly, high $V p / V s(1.80-1.89)$ is suggested if we accept the M1 depth based on previous studies [Christeson et al., 1999; Sallarès et al., 2001; DeShon et al., 2006] and determine the $V p / V s$ by migrating the $P s$ time of the receiver functions along the strike of the subducting Cocos Plate. Unfortunately, we cannot reliably estimate the $V p / V s$ in this way, as synthetic tests for a layer dipping $>30^{\circ}$ predict that the $V p / V s$ could be 0.08 higher than the one estimated from the Ps time only.

\section{3. $H-\kappa$ Sensitivity to the Assumed $V p$}

[32] The sensitivity of the $H-\kappa$ stacking algorithm to the assumed $V p$ is examined by creating a map of the bias for both the depth and $V p / V s$ estimates for a range of $V p$ values and interface depths. We found that the $H-\kappa$ stacking algorithm is not particularly sensitive to $V p$. If the $V p$ deviation is $<0.4 \mathrm{~km} / \mathrm{s}$ from the correct input value (i.e., $V p$ in the model is $6.3 \mathrm{~km} / \mathrm{s}$ and a value of $6.3 \pm 0.4 \mathrm{~km} / \mathrm{s}$ is used instead in the $H-\kappa$ algorithm, Figure 6) the $V p / V s$ estimate differs from the initial model by $< \pm 0.02$ in $V p / V s$ and $< \pm 3 \mathrm{~km}$ in depth, for models with interface depths in the range from 10 to $45 \mathrm{~km}$. A larger bias in the depth estimate is expected for models with interface depths $>45 \mathrm{~km}$. In this study, we do not expect the assumed crustal $V p$ (Table 1) to significantly affect the overall findings, as 
Geochemistry

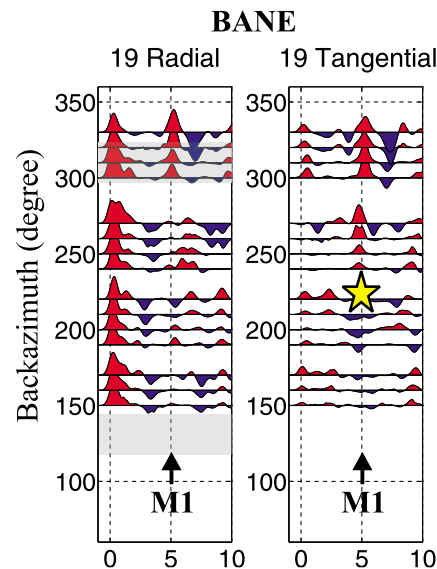

JUDI

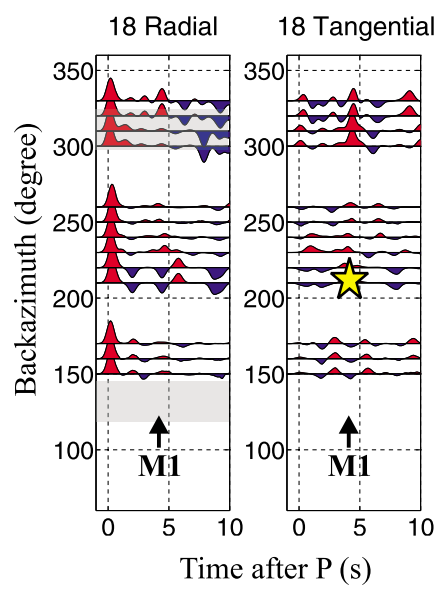

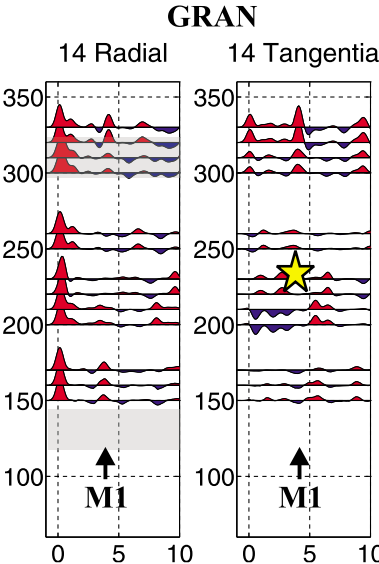

MARB

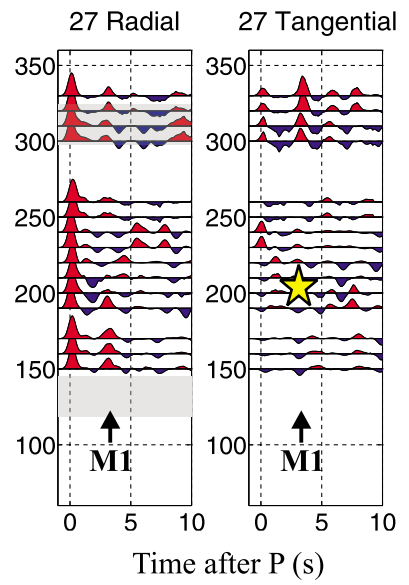

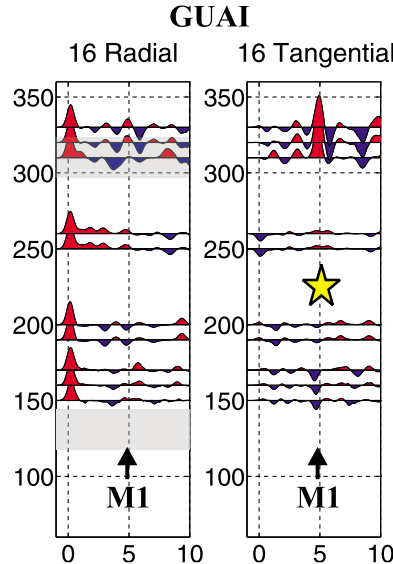

PAPA

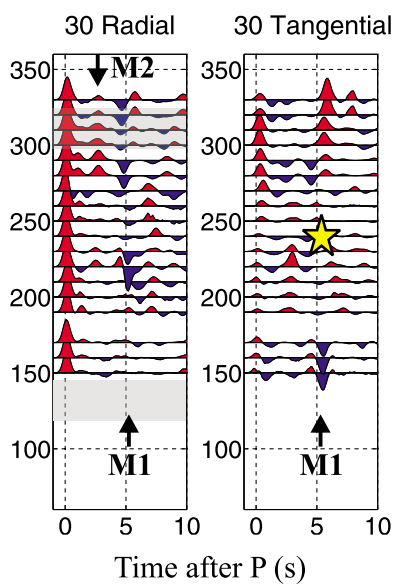

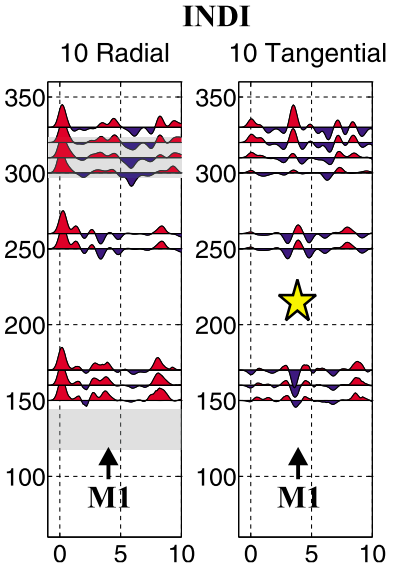

PNCB

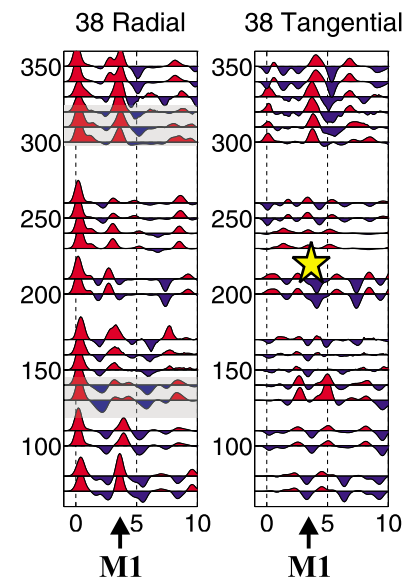

Figure 7. Receiver functions binned over $10^{\circ}$ for stations in the Nicoya Peninsula region. Receiver functions are normalized to the maximum amplitude. Station name and number of receiver functions are given above each plot. Positive and negative amplitudes are shaded red and blue, respectively. Black arrows mark the location of the signal correlated to the oceanic Moho (M1), and yellow stars denote the location of the polarity reversal common to all stations. Gray areas mark the radial receiver functions stacked along the strike of the dipping Cocos Plate shown in Figure 8.

deviations greater than $\pm 0.4 \mathrm{~km} / \mathrm{s}$ in the assumed $V p$ are unlikely.

\section{Results and Discussion}

\subsection{Subducting Cocos Plate Beneath the Nicoya Peninsula}

[33] We detected M1 in the Nicoya Peninsula region as a clear positive $P S$ at delay times from 3 to $5 \mathrm{~s}$ in the radial receiver functions (Figures 7 and 8). The following features of M1 are consistent with a northeast dipping interface in agreement with the direction of the subducting Cocos Plate: (1) the arrival time of the $P S$ signal at different sites increasing toward the northeast; (2) a polarity reversal at $200-240^{\circ}$ in the tangential component of all stations, suggesting that the direction of maximum dip is $\sim \mathrm{N} 40^{\circ} \mathrm{E}$; (3) a clear positive arrival in the tangential component in the back azimuth range from $300^{\circ}$ to $340^{\circ}$; and (4) a negative arrival in the tangential component in the back azimuth range from $150^{\circ}$ to $180^{\circ}$ at most stations. All these features were reproduced by creating synthetic receiver functions using simple models of a shallow northeast dipping interface over a half-space (Figure 9). However, the comparison of observed and synthetic receiver functions does not resolve the finer features and is mostly confined to the first $10 \mathrm{~s}$ where complications of dipping structures are minimized.

[34] Our depth estimates (Table 1) are in agreement with the location of M1, about $7 \mathrm{~km}$ deeper than the top of the slab estimated from refraction seismology [Christeson et al., 1999] and WBZ seismicity [DeShon et al., 2006]. To explore the possibility that the $P s$ corresponds to the top of the 


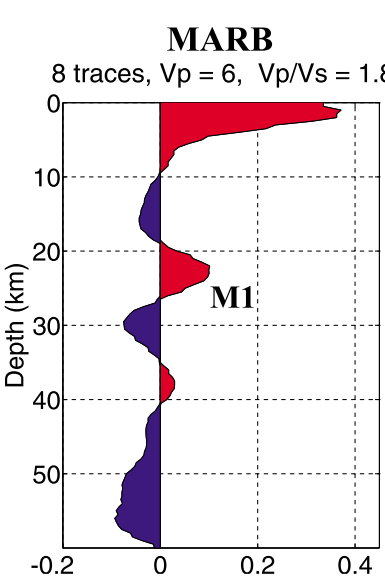

INDI
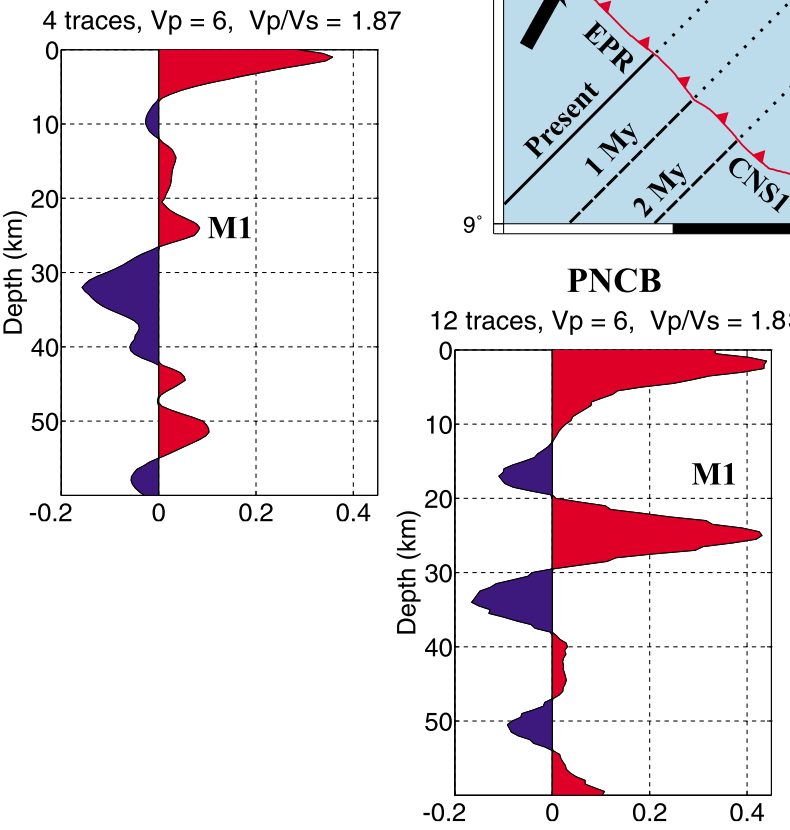

PNCB
PAPA

GRAN

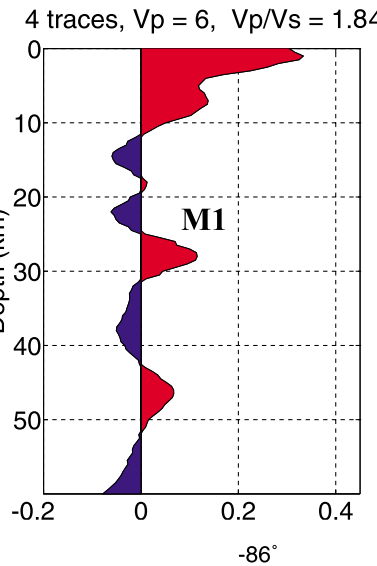

11 traces, $\mathrm{Vp}=6.3, \mathrm{Vp} / \mathrm{Vs}=1.62$

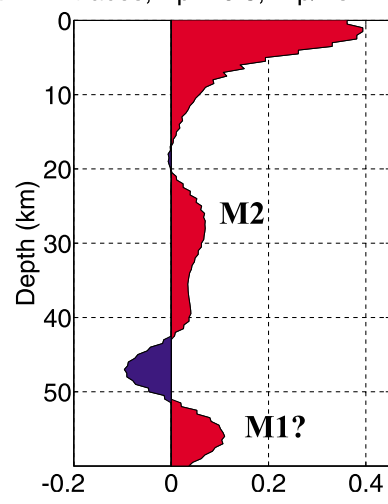

$-85^{\circ}$
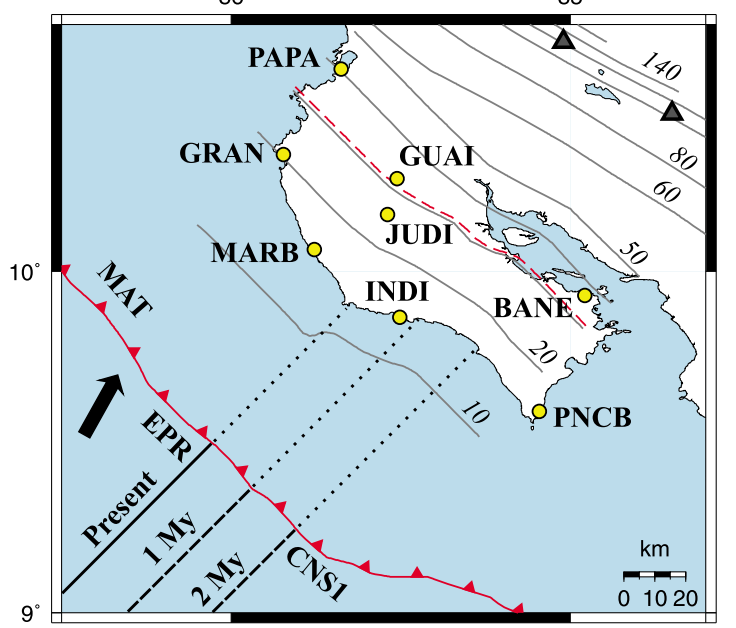

BANE

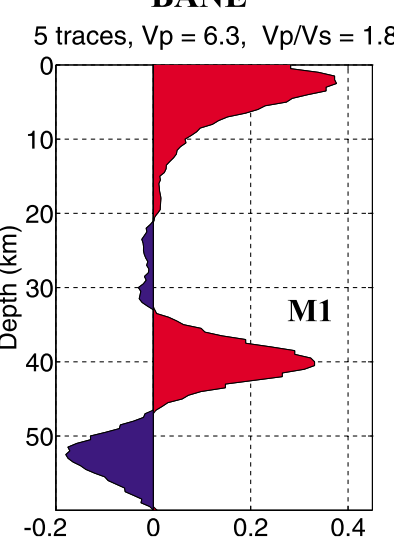

GUAI

4 traces, $\mathrm{Vp}=6.3, \mathrm{Vp} / \mathrm{Vs}=1.83$

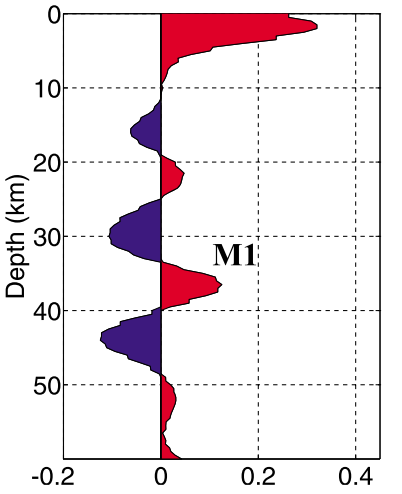

JUDI

4 traces, $V p=6.3, V p / V s=1.89$

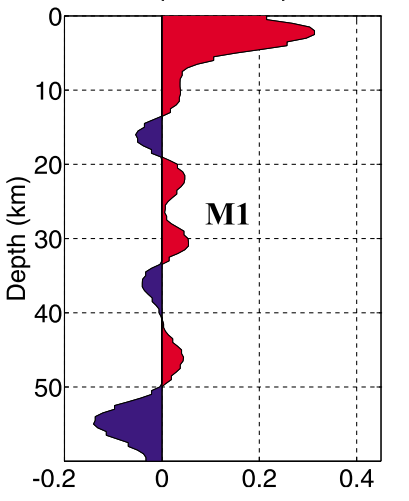

Figure 8. Absolute amplitude receiver functions for CRSEIZE stations stacked along the strike of the subducting Cocos Plate. Station name, number of receiver functions, and $V p$ and $V p / V s$ ratio used for migrating time to depth are given above each plot. M1 and M2 denote oceanic and upper plate Moho, respectively. The center map shows slab contours (in km) to the top of the subducting Cocos Plate according to DeShon et al. [2006] and Protti et al. [1994] and the location of the EPR-CNS1 suture at specified geologic times, based on Barckhausen et al. [2001]. Other symbols and acronyms as in Figure 1.

slab, we calculated the $V p / V s$ required for the $P s$ to be migrated to that depth. We performed this analysis assuming a constant crustal $V p$ for each station (Table 1) and using only receiver functions along the strike of the subducting Cocos Plate, because complications in the stacking are minimized in the strike direction (section 5.1, Figures 4 and 8). Sensitivity tests revealed that the bias in 
a) Hydrated oceanic crust and serpentinized mantle

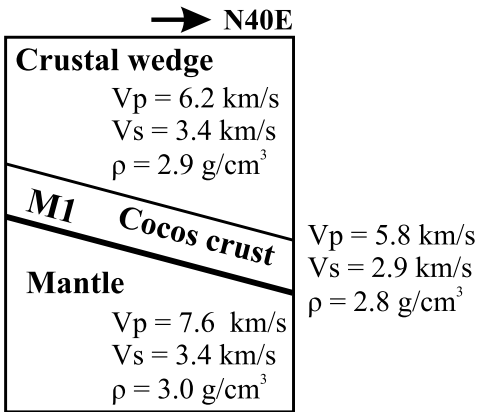

d) Moderately hydrated oceanic crust and mantle

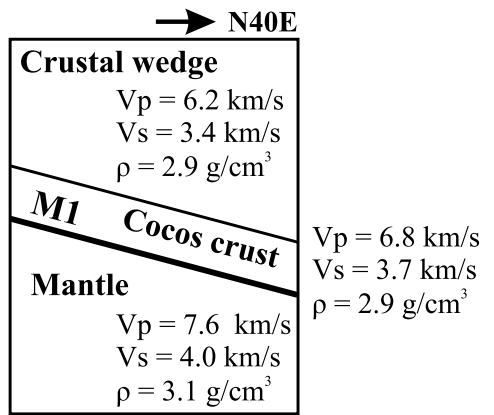

g) Hydrated oceanic crust and drier mantle

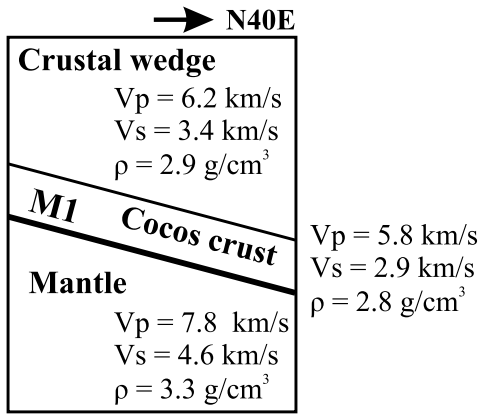

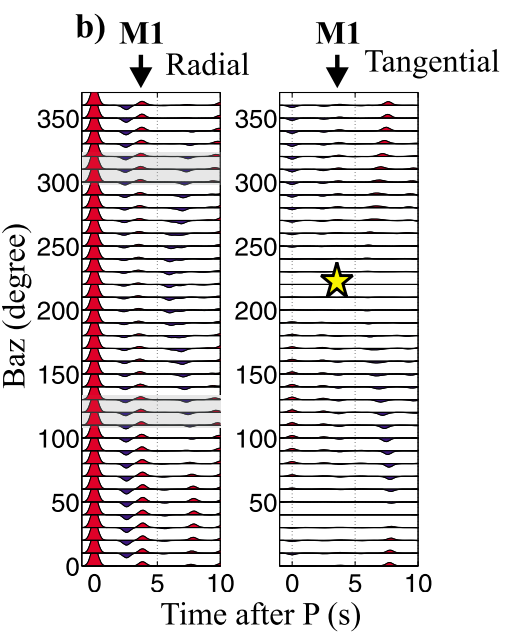
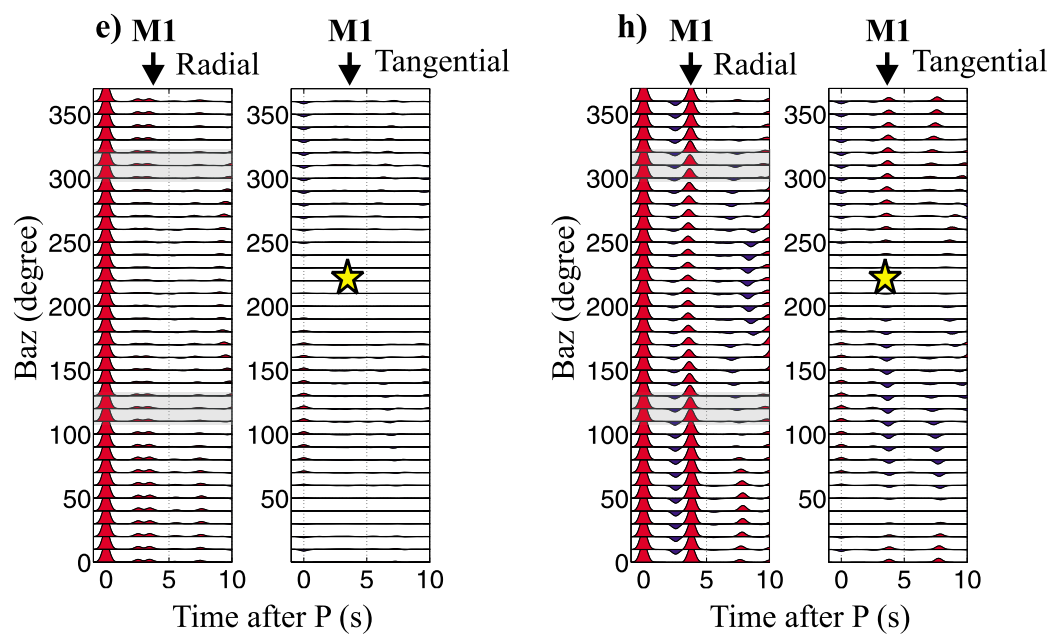

c)

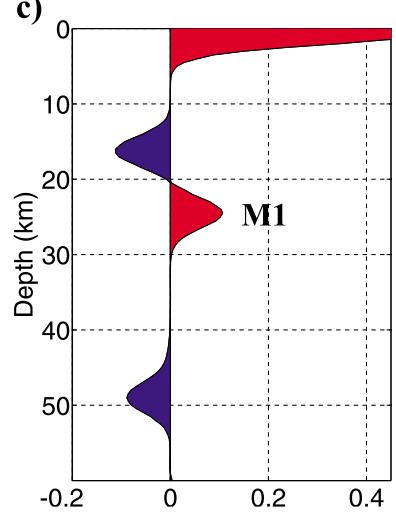

f)

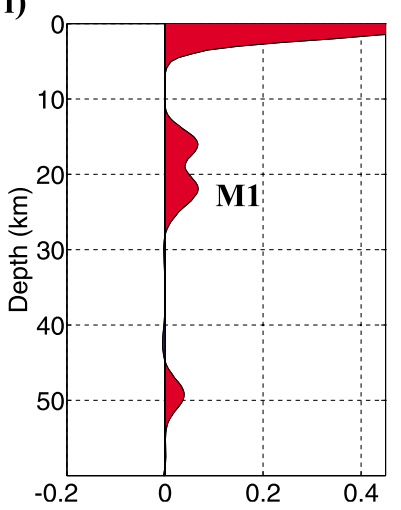

i)

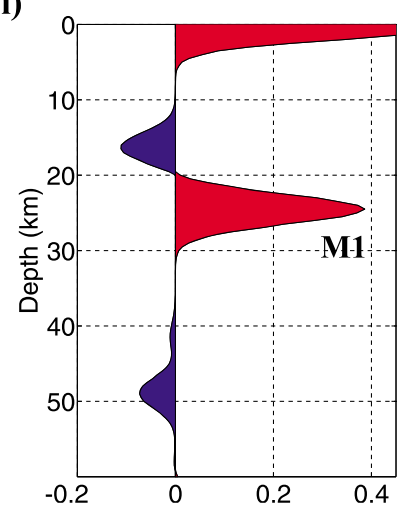

Figure 9. Synthetic receiver functions for simple models recreating the subducting Cocos Plate beneath a mafic crustal wedge over a $(\mathrm{a}-\mathrm{f})$ hydrated and $(\mathrm{g}-\mathrm{i})$ dry oceanic mantle. In the schematic velocity structures (Figures 9a, $9 \mathrm{~d}$, and $9 \mathrm{~g}$ ) the subducting Cocos crust is $7 \mathrm{~km}$ thick, dipping $15^{\circ}$ toward $\mathrm{N} 40^{\circ} \mathrm{E}$, and the oceanic Moho (M1) is at $25 \mathrm{~km}$ depth. Synthetic receiver functions were calculated every $5^{\circ}$ in back azimuth and with a constant ray parameter of 0.068 (Figures 9b, 9e, and 9h). Black arrows at the top of the plots mark the location of the signal correlated to M1, and yellow stars denote the location of polarity reversals. Gray areas mark the radial receiver functions stacked along the strike of the dipping interface shown as an absolute amplitude stack (Figures 9c, 9f, and 9i).

calculating the $V p / V s$ using the $P s$ time of alongstrike receiver functions is only $\sim 0.01$, for an interface dipping $13^{\circ}$, as expected for M1 beneath the coast line. We found that the $V p / V s$ required for the $P s$ conversion to be migrated to the top of the slab is unrealistically high $(\sim 2.25)$. On the other hand, a $V p / V s$ of $1.80-1.85$, which is in agreement with our corrected $\mathrm{Vp} / \mathrm{Vs}$ solutions from the $H-\kappa$ algorithm, places the interface depth at $21-25 \mathrm{~km}$, which is the expected M1 depth. Hence, we inter- 
pret the observed $P s$ as produced at M1 and not at the top of the oceanic crust.

[35] There are some receiver function features that may correlate to the top of the oceanic crust but are not consistent at all stations and back azimuths. For example, receiver functions at stations INDI and JUDI, in central Nicoya, show an additional positive arrival about $1 \mathrm{~s}$ earlier than M1 at some back azimuths (Figure 7). If this signal corresponds to the top of the slab, it would require an increase in wave speed across the top of the oceanic crust. For stations BANE and PNCB there is a negative arrival about $1 \mathrm{~s}$ before the M1 Ps over a broad back azimuth range, especially at PNCB (Figure 7). A negative arrival is also present at some back azimuths at stations MARB and GRAN (Figure 7). In all these cases, the negative polarity arrival characterizes higher to lower wave speeds with increasing depth, indicating a low-velocity zone.

[36] A strong negative polarity reflection from the top of the subducting Cocos Plate has been interpreted as caused by free water coming from dehydration reactions of subducted clays [Ranero et al., 2008]. Low-velocity anomalies parallel to the top of the subducting plate and detected using receiver functions have also been correlated with a hydrated subducting oceanic crust in southern Alaska [e.g., Rossi et al., 2006], northeast Japan [e.g., Kawakatsu and Watada, 2007], and Cascadia [Nikulin et al., 2009] subduction zones. As the observed negative arrival is not consistent at all stations and back azimuths, we are not able to discriminate whether this feature indicates a hydrated subducting oceanic crust or a hydrated base of the overriding plate.

\subsection{Hydration State Variability in the Subducting Cocos Plate}

[37] The Ps amplitude observed at stations located in the Nicoya Peninsula reveals a very interesting pattern. The M1 amplitude from stations located in the southernmost part of the peninsula (i.e., BANE and PNCB-MOSD) is considerably larger compared to that observed at stations located in the central and northern parts (Figure 8). Because the amplitude of receiver functions scales with the velocity contrast at the interface, a larger impedance contrast at the base of the oceanic crust (M1) is likely for stations located in the southernmost part of the Nicoya Peninsula.

[38] Oceanic crust generated at both the EPR and CNS1 subducts beneath the northern and southern half of the Nicoya Peninsula, respectively (Figure 1).
While both types of lithosphere are of similar age at the MAT (21-24 Ma), there is a distinct thermal change across the EPR-CNS1 suture. Heat flow measurements in the $24 \mathrm{Ma}$ EPR crust average $14 \mathrm{~mW} / \mathrm{m}^{2}$ [Langseth and Silver, 1996], which is exceptionally low when compared to the heat flow of $\sim 100 \mathrm{~mW} / \mathrm{m}^{2}$ expected for a 20-25 Ma oceanic crust [Stein and Stein, 1992]. In contrast, heat flow measurements in the similarly dated (21-23 Ma) CNS1 crust have values of $105-115 \mathrm{~mW} / \mathrm{m}^{2}$ which are higher than the heat flow values expected from global models [Fisher et al., 2003].

[39] The effective hydrothermal cooling of the EPR-generated seafloor has been attributed to an unusually high permeability facilitated by the presence of outer rise normal faulting [Grevemeyer et al., 2005]. Seismic reflection images acquired in the EPR-generated seafloor, offshore Nicaragua, show a pervasive set of trenchward dipping features that cross the crust and extend into the upper mantle to depths of $\sim 20 \mathrm{~km}$ [Ranero et al., 2003; Grevemeyer et al., 2007]. In this region, tomographic images revealed anomalously low $V p$ in the uppermost mantle, suggesting $12 \%-17 \%$ serpentinization [Ivandic et al., 2008]. This observation supports the idea that pervasive bending-related normal faulting in the subducting slab is creating pathways for seawater to hydrate upper mantle rocks [Grevemeyer et al., 2007; Ivandic et al., 2008] and it is also consistent with the hypothesis that the stronger slab signal in the volcanic arc geochemistry inland of the EPR segment is reflecting greater amounts of fluid released from dehydration of a more extensively serpentinized EPR mantle [Rüpke et al., 2002]. In contrast, the CNS1generated seafloor displays only a few small-offset faults in the outer rise [Ranero et al., 2003].

[40] Figure 8 shows the location of the EPR-CNS1 suture zone, at present time and 1 and $2 \mathrm{Ma}$, based on Barckhausen et al. [2001]. Assuming that the current plate velocity vectors have remained constant during the last $2 \mathrm{Ma}$, we expect that the oceanic lithosphere visible beneath the southernmost part of the Nicoya Peninsula has CNS1 origin. In contrast, the oceanic lithosphere beneath stations in central and northern Nicoya corresponds to EPR origin, with the exception of station INDI, which likely originated near the EPR-CNS1 suture region.

[41] We created synthetic receiver functions for simple models involving hydrated and dry oceanic crust and upper mantle, to recreate the subduction 
of EPR and CNS1 lithospheres (Figure 9). As expected, the $P s$ amplitude is considerably larger in the presence of a hydrated oceanic crust over a dry upper mantle (Figures 9g-9i) and smaller if the oceanic mantle is serpentinized (Figures 9a-9c). Differences in the hydration state of the subducting oceanic crust may account for the amplitudes observed at some back azimuths at INDI and JUDI (Figures 9d-9f). In order to reproduce the $P S$ amplitude observed in our receiver functions, a $V s$ contrast of $0.3-0.5 \mathrm{~km} / \mathrm{s}$ is required at $\mathrm{M} 1$ for stations located above the EPR segment and a much larger $V s$ contrast of $1.7 \mathrm{~km} / \mathrm{s}$ is required for the CNS1 segment.

[42] The observed Ps conversions in the Nicoya region are then consistent with a hydrated oceanic crust and a drier oceanic mantle being subducted beneath the southernmost part the Nicoya Peninsula, as compared to a variably hydrated oceanic crust and serpentinized EPR oceanic mantle subducting beneath central and northern Nicoya. Pervasive bending-related normal faulting in the EPR segment may extend through the entire oceanic crust and facilitates the hydration of both the oceanic crust and upper mantle, as opposed to the CNS1 segment, where hydration may occur only within the oceanic crust, resulting in a low-velocity layer beneath the southernmost part of the peninsula. Hence, our receiver function observations are in agreement with previous studies which suggest a serpentinized EPR oceanic mantle and a drier CNS1 oceanic mantle; based on outer rise fault patterns [Ranero et al., 2005] and the thermal state [Fisher et al., 2003] of both Cocos Plate segments, as well as volcanic arc geochemistry [Rüpke et al., 2002].

\subsection{Upper Plate Moho (M2) and $H-\kappa$ Estimates}

[43] We identified M2 for individual stations beneath the fore-arc (JTS, PAPA-COND, and SARO), volcanic arc (HDC), and back-arc (JOC-TIR) regions (Figures 10 and 11a). The M2 Ps amplitude is consistent with $V s$ contrasts of $0.5-1.0 \mathrm{~km} / \mathrm{s}$. Combining our results with those presented by MacKenzie et al. [2008] (Figure 12a), we see that the deepest M2 is observed in the volcanic arc region $(\sim 40-42 \mathrm{~km})$ and the shallowest M2 in parts of the fore arc (29-33 km, Papagayo Gulf region) and back arc (27-33 km, Nicaragua border region).

[44] In the fore-arc region, beneath station JTS, we identified the M2 Ps at $4 \mathrm{~s}$ from northwest (back azimuth $235-330^{\circ}$ ) and northeast $\left(40-135^{\circ}\right)$ direc- tions and at $5 \mathrm{~s}$ from southern $\left(135-235^{\circ}\right)$ directions (Figure 10a). Moveout analysis for each back azimuth subsets revealed that the signal observed is a $P S$ and not a multiple. We calculated synthetic receiver functions based on simple models and concluded that the complex azimuthal behavior of the M2 $P s$ in the region sampled beneath JTS (Figure 11b) is difficult to reproduce and may reflect a complex Moho topography or a combination of factors including dip, a significant azimuthal variation in the crustal $V p / V s$ on a local scale, and/or seismic anisotropy. If exposures of oceanic assemblages at Tortugal (Figure 11b), for which high $V p / V s$ are expected, continues at depth in the region south of JTS, they may account for the $P S$ time delay from the southern direction. Our more robust $H$ and $\kappa$ estimates for JTS come from the northwest subset, for which we calculated a Moho depth of $36.7 \pm 2.4 \mathrm{~km}$ and crustal $V p / V s$ of $1.69 \pm$ 0.05 (Figure 11a), similar to previous estimates of $41 \pm 7.3 \mathrm{~km}$ and $1.78 \pm 0.06$ using 24 receiver functions [MacKenzie et al., 2008] and $36 \pm 4 \mathrm{~km}$ determined by best fitting synthetic and observed receiver functions [DeShon and Schwartz, 2004].

[45] In the central segment of the volcanic arc region, beneath station HDC, M2 is observed as a clear positive $P s$ at $\sim 6 \mathrm{~s}$, and is particularly clear in the back azimuth range from $290^{\circ}$ to $360^{\circ}$ (Figure 10a). We observed a well-developed M1 $P p P s$ multiple as well as a negative conversion at $3 \mathrm{~s}$, which represents a low-velocity layer in the midcrust (Figure 10b). Our more robust $H-\kappa$ estimates come from a northwest subset $\left(290-360^{\circ}\right.$, Figure 11a) for which we obtained $41.7 \pm 2.3 \mathrm{~km}$ and $1.92 \pm 0.05$ (Table 1). MacKenzie et al. [2008] obtained $37.0 \pm 2.3 \mathrm{~km}$ and $1.87 \pm 0.08$ for a station (HDC5) located at HDC by using 20 receiver functions that spanned the duration of the TUCAN deployment.

[46] In the back arc, beneath stations of the Pocosol network (JOC-TIR), we observed a coherent M2 $P s$ at $\sim 4$ s (Figure 10a) and a well-developed PpPs multiple (Figure 10b). Our more robust solution comes again from a northwest subset $\left(260-360^{\circ}\right)$ for which we obtained $28.7 \pm 1.4 \mathrm{~km}$ and $1.85 \pm$ 0.06 (Table 1).

\subsection{Crustal Terranes in Northern Costa Rica}

\subsubsection{Mesquito Terrane}

[47] We link the crustal $V p / V s$ ratios observed in the Costa Rica-Nicaragua border region (1.82- 
Geochemistry

a)

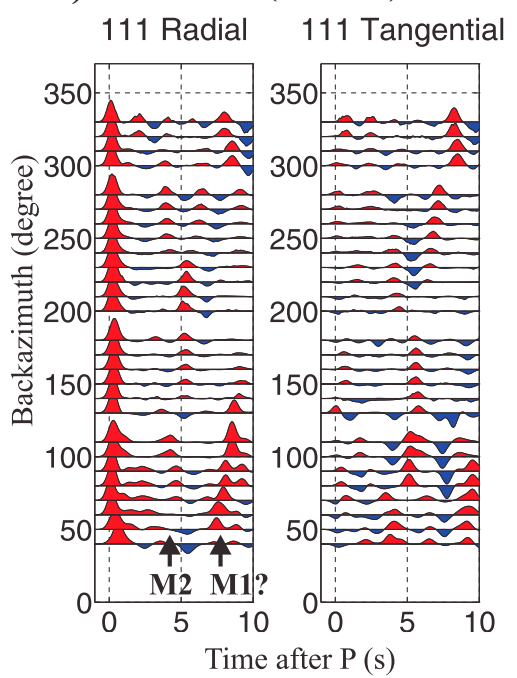

b) JTS (Forearc)

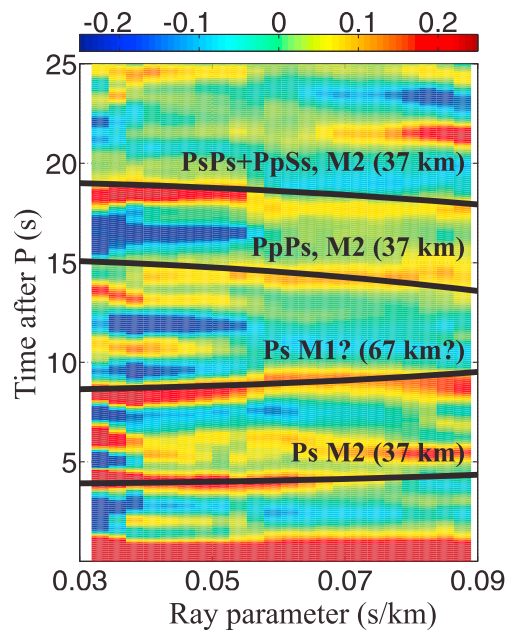

HDC (Arc)

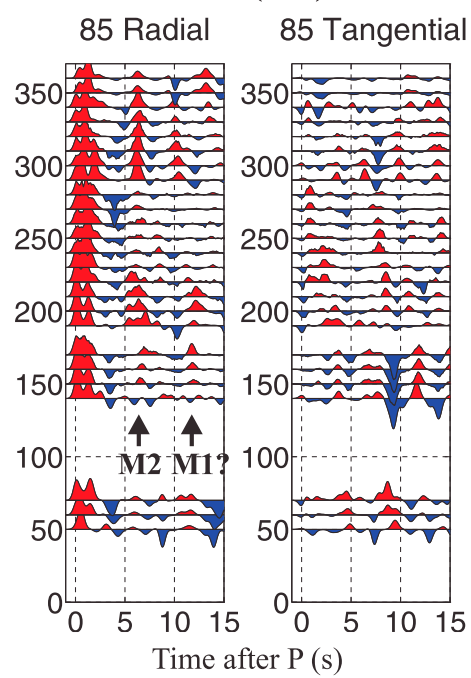

HDC (Arc)

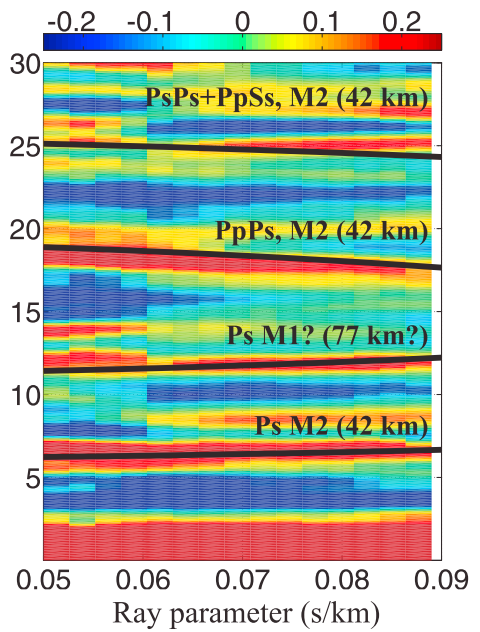

JOC-TIR (Backarc)

46 Radial 46 Tangential

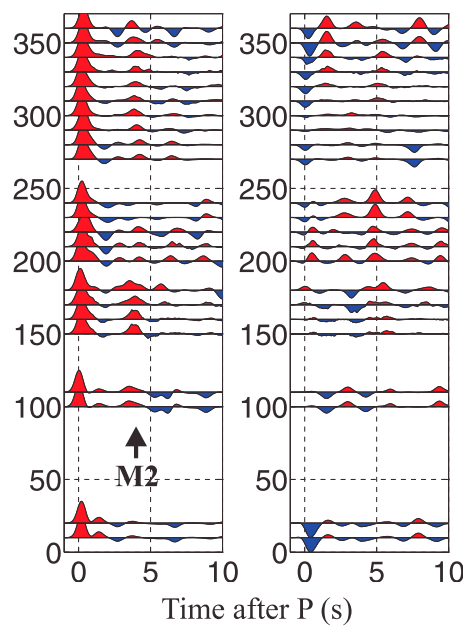

JOC-TIR (Backarc)

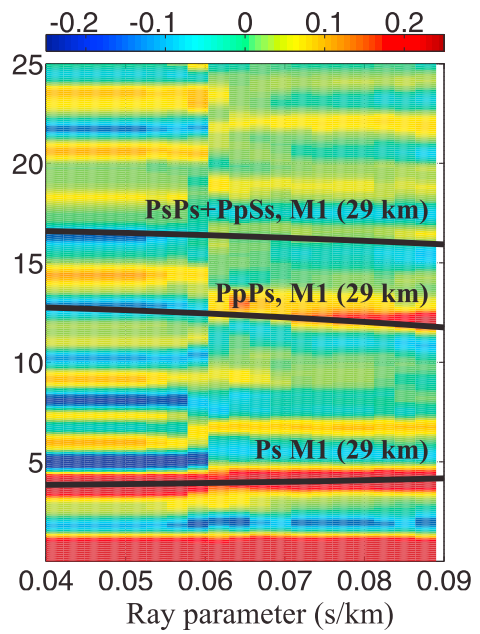

Figure 10. (a) Receiver functions binned over $10^{\circ}$ for the specified stations at the top of each plot. (b) Amplitude plots of the radial component of receiver function as a function of ray parameter for the specified stations. Color bars at the top of each plot denote the scale of normalized amplitude receiver function. Black lines show the predicted moveout of Ps conversions and multiples for the slab (M1?) and upper plate Moho (M2) using the specified depths (shown in parentheses) and $V p / V s$ obtained from the $H-\kappa$ algorithm (Figure 11a).

1.88), Papagayo Gulf region (1.62-1.67), and Nicoya Gulf and northern volcanic arc segment $(1.68-1.80)$ to the Mesquito Terrane (Figures 12 and 13). The Mesquito Terrane is composed of a collage of Pacific oceanic terranes that includes both enriched OIB and depleted arc rocks [Baumgartner et al., 2008] and may represent the Late Cretaceous basement upon which fragments of the CLIP were accreted during Late Cretaceous-Miocene, as interpreted for the Santa Elena-Tortugal area (Figure 13a) by Denyer and Gazel [2009].

[48] The high $V p / V s(1.82-1.88)$ in the Costa Rica-Nicaragua border region is consistent with mafic lithologies and/or partially serpentinized peridotites [e.g., see Rudnick and Fountain, 1995; Horen et al., 1996; Carlson and Miller, 1997; Christensen, 2004]. Serpentinized peridotites (Figure 13a) are found in the Santa Elena Peninsula (i.e., Santa Elena Nappe), El Castillo, and in the Tonjibe borehole as a $\sim 200 \mathrm{~m}$ thick layer at $\sim 2 \mathrm{~km}$ depth [Astorga, 1992; Pizarro, 1993]. In the Santa Elena Peninsula, these rocks have an island arc affinity and have been interpreted as an uplifted mantle wedge of the Chortis subduction zone [Hauff et al., 2000]. Other lithologies that may be correlated to the Mesquito Terrane are the alkaline basalts of the Tortugal Suite, located east of the 
a) JTS: $\mathrm{Vp}=6.5 \mathrm{~km} / \mathrm{s}$

$V p / V s=1.69, \mathrm{M} 2$ at $37 \mathrm{~km}$

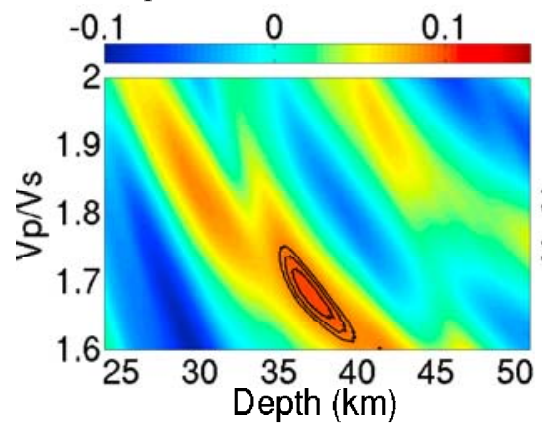

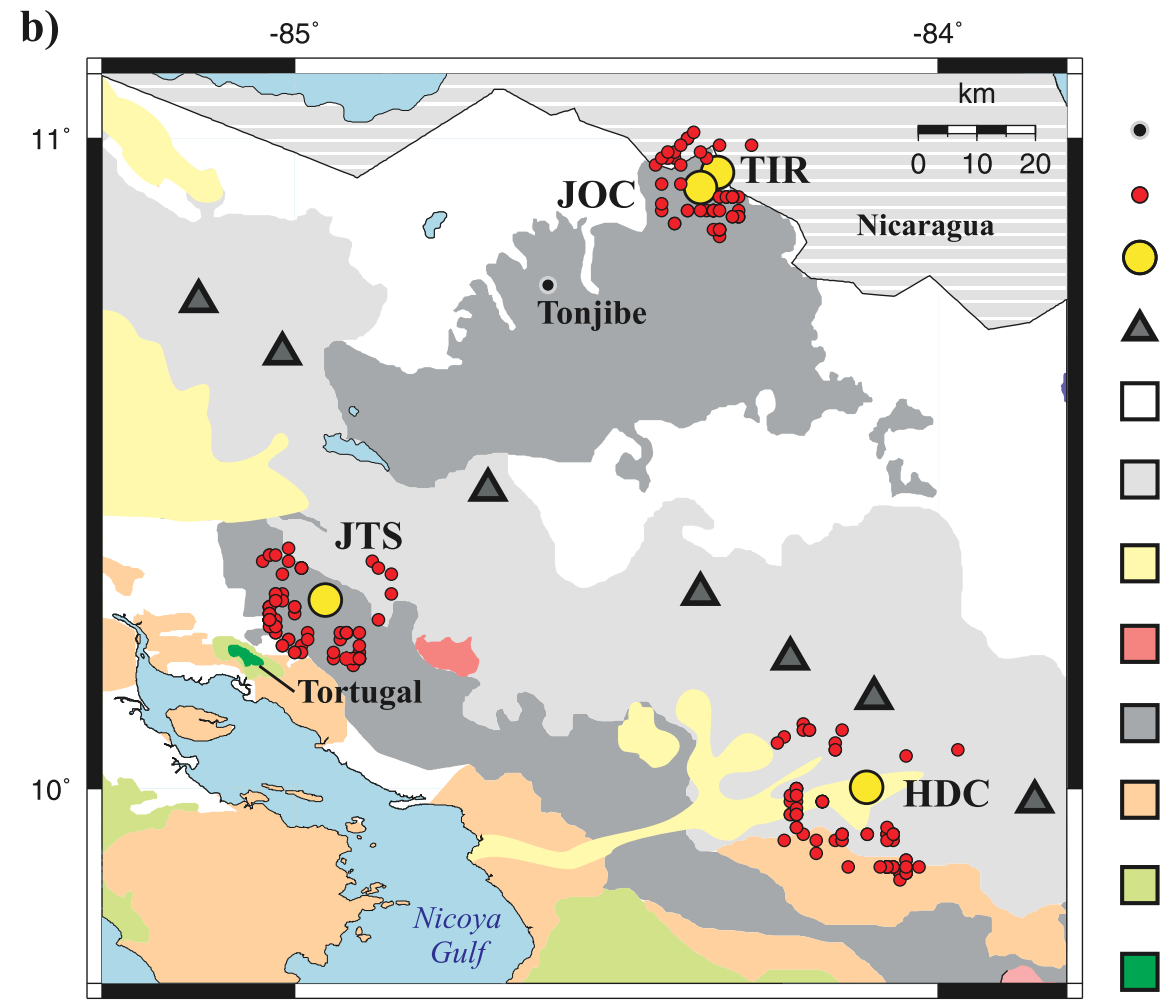
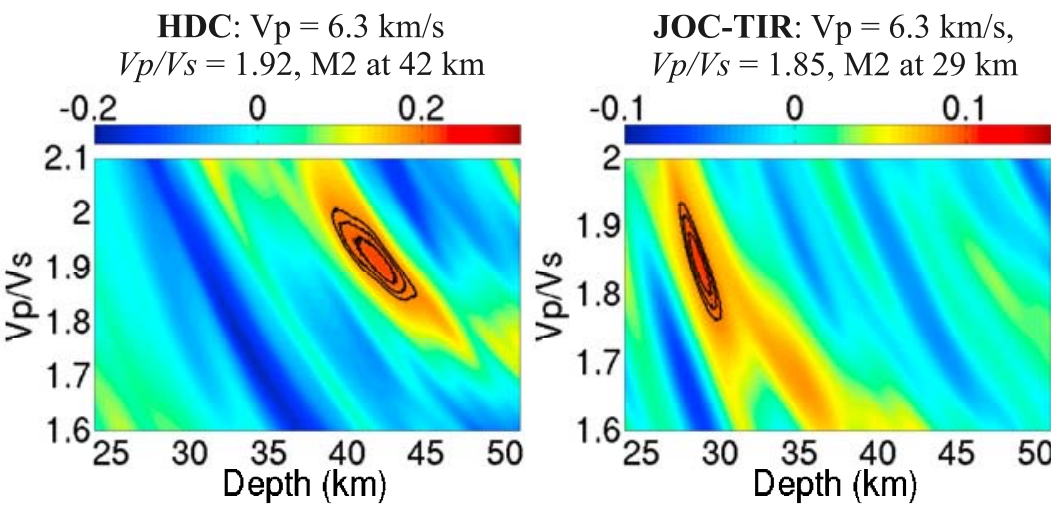

\author{
Oil borehole \\ Piercing point \\ Station \\ Holocene volcano \\ Sediments (Quaternary) \\ Basalt to dacite \\ (Quaternary) \\ Dacite-rhyolite ignimbrites \\ (Pliocene-Quaternary) \\ Intrusive rocks \\ (Miocene) \\ Basalt to dacite \\ (Miocene-Pliocene) \\ Sedimentary rocks \\ (Mesozoic-Cenozoic) \\ Oceanic assemblages \\ (Cretaceous-Eocene) \\ Serpentinized peridotites \\ and non-CLIP-related \\ oceanic assemblages
}

Figure 11. (a) Amplitude $H-\kappa$ stacks for specified stations. Depth to M2 and crustal $V p / V s$ ratio for each maximum are given above each plot. Black contours delineate regions with $85 \%, 90 \%$, and $95 \%$ of the maximum amplitude. Color bars at the top of each plot denote the amplitude scale for the stacked receiver functions. (b) Map of the predicted location of points piercing M2 for the specified stations and depths in Figure 11a.

Nicoya Gulf (Figure 13a), as well as those exposed in the Santa Elena Peninsula (i.e., Santa Rosa Accretionary Complex). These basalts have OIB affinity without Galapagos signature [Hauff et al., 2000]. If partially serpentinized peridotites together with mafic lithologies are widespread in the midcrust and/or lower crust, these rocks could account for the high $V p / V s$ ratios observed in the Costa Rica-Nicaragua border region.

[49] Within the Mesquito Terrane, there is a progressive decrease in the crustal $V p / V s$ from higher
$(1.82-1.88)$ in the back arc near Lake Nicaragua to lower (1.74-1.79) in the volcanic arc to even lower (1.68-1.74) near the Nicoya Gulf (Figure 12b) [MacKenzie et al., 2008]. As silicic rocks have low $V p / V s$ [Christensen, 1996], this pattern may imply a transition from a mafic/ultramafic crust in the back arc to a more quartz-rich felsic crust in the inner fore arc. The global $V p / V s$ averages for the continental and oceanic crusts are 1.78 and 1.87, respectively [Zandt and Ammon, 1995; Christensen, 1996]. Then, the $V p / V s$ in the Papagayo and Nicoya 


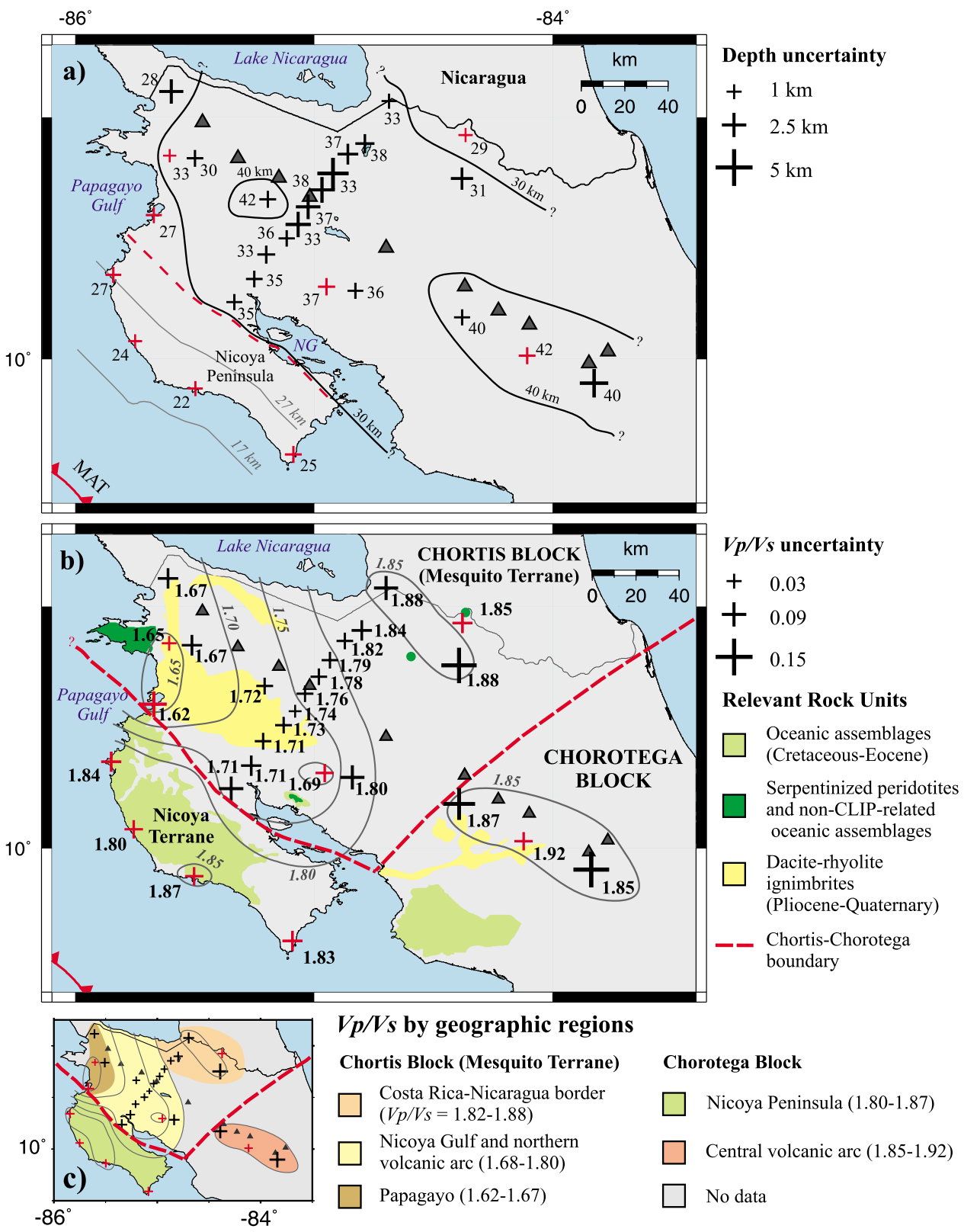

Figure 12. (a) Map of Moho depth (in km). Gray lines represent contours to M1, and red dashed line denotes the slab-M2 intersection based on DeShon et al. [2006]. (b) Map of the crustal Vp/Vs. Estimates for red crosses were calculated in this study. The remaining estimates come from MacKenzie et al. [2008]. Note that symbol size scales to uncertainties, as defined on the right side of each map. (c) $V p / V s$ by geographic regions as described in section 6.4. See Figure 2 for station names and explanation of symbols. NG, Nicoya Gulf.

Gulf regions, as well as in the northern volcanic arc segment, are more compatible with lithologies constituting continental crust rather than mafic oceanic crust. These $V p / V s$ values are somewhat surprising, given that most studies agree that the modern volcanic arc in Costa Rica is built either on the Chorotega or the Mesquito terranes [Baumgartner et al., 2008, and references therein].

[50] Interestingly, extensive silicic magmatism, dominated by rhyolitic ignimbrites, has occurred in the Guanacaste region (Figures 2a and 13a) since the Miocene, suggesting the formation of new continental crust [Vogel et al., 2004]. Additional evidence for continental crust formation is given by Sallarès et al. [2001], who obtained velocity-density relationships for the lower crust and upper mantle comparable to continental island arcs. Moreover, the crustal thickness in Costa Rica is nearly double the average for the CLIP [MacKenzie et al., 2008]. We suggest that the low to moderate 

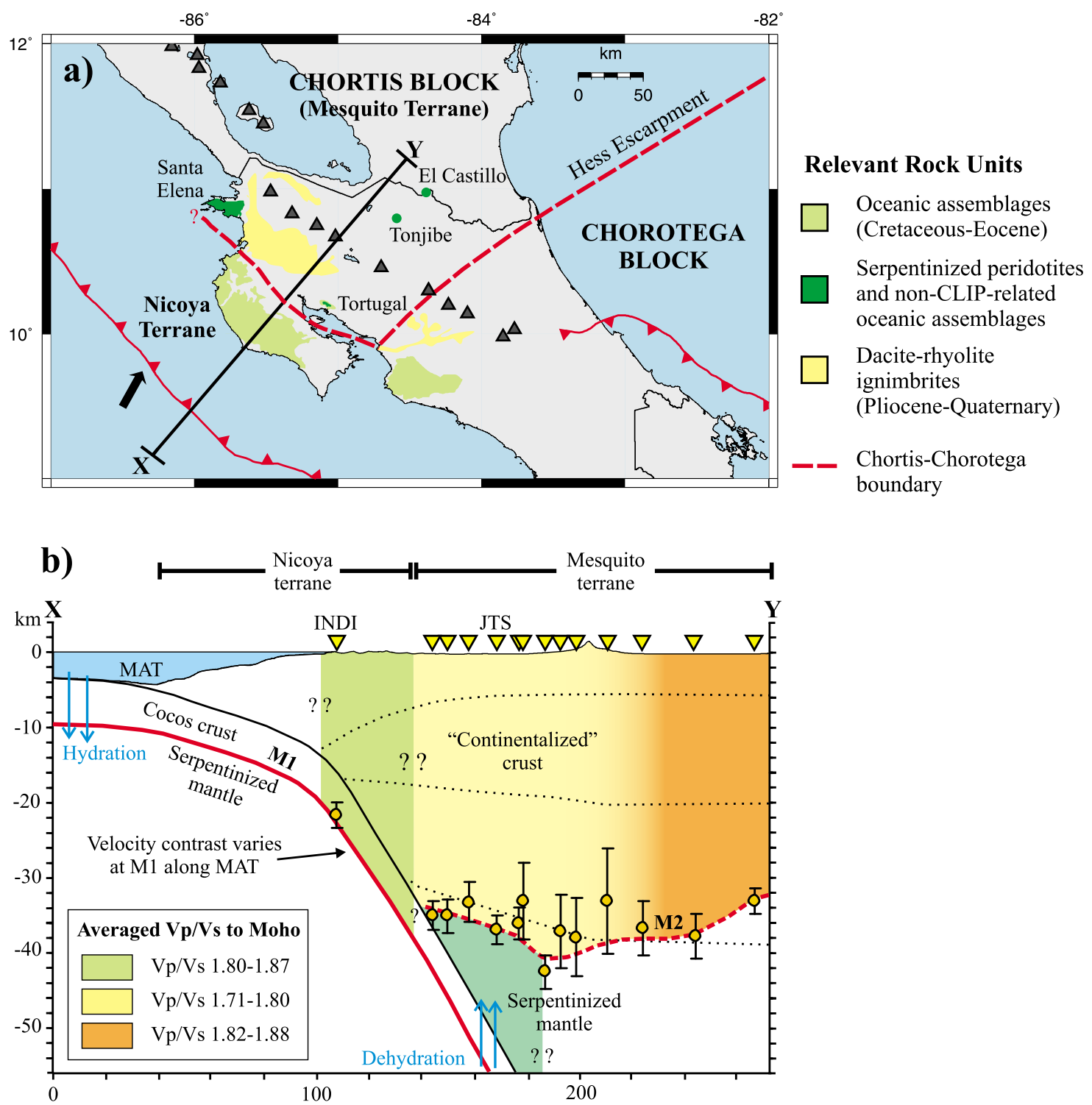

Figure 13. (a) Generalized interpretation of terrane boundaries integrating results from this study, Hauff et al. [2000], and Baumgartner et al. [2008]. (b) Generalized interpretation along the X-Y cross section shown in Figure 13a integrating results from this study, MacKenzie et al. [2008], Sallarès et al. [2001], and DeShon and Schwartz [2004]. Depth estimates are shown as yellow circles with error bars. Depth and $V p / V s$ for station INDI correspond to the oceanic Moho (M1), while the remaining estimates correspond to the upper plate Moho (M2). A possible M2 interpretation is sketched as a dashed red line. Inverted triangles represent broadband stations located $<13 \mathrm{~km}$ from cross section. Station JTS, located $30 \mathrm{~km}$ from the profile, was also projected onto the cross section. Note vertical scale is three times the horizontal scale. Terranes, as interpreted at surface, are shown at the top of the plot. The orientation of terrane boundaries at depth is unknown. Colors represent crustal regions with distinct vertically averaged $\mathrm{Vp} / \mathrm{Vs}$.

$V p / V S$ in the fore-arc and volcanic arc regions of northern Costa Rica, together with the record of voluminous silicic magmatism, seismic velocities, and crustal thickness support the idea of new continental crust formation. Perhaps the addition of silicic magma to the crust, together with the removal of the mafic/ultramafic residues and cumulates from the base of the crust, as has been proposed for other regions [e.g., Zandt et al., 2004], have lead to the modification of this crust over time into a more continental-type crust.

\subsubsection{Chorotega Block}

[51] The high $V p / V s$ ratios (1.85-1.92, Figure $12 \mathrm{~b})$ in the central Costa Rica volcanic arc segment are consistent with mafic lithologies constituting the 
CLIP. The very high $V p / V s$ found at station HDC could be also explained by the presence of partial melts in the midcrust and/or beneath this part of the volcanic arc, as we observed a negative conversion at $3 \mathrm{~s}$, which represents a low-velocity layer in the midcrust (Figure 10b). In the Nicoya Peninsula (Nicoya Terrane), the $V p / V s$ varies from 1.80 to 1.87 (Figure 12b and Table 1), which is similar to the average $V p / V s$ for ophiolite exposures in the world; for example, the Samail (Oman) and the Newfoundland (Canada) ophiolites have average $V p / V s$ of 1.88 and 1.89 , respectively [Christensen, 1996]. This suggests that the entire crustal wedge beneath the Nicoya Peninsula may be composed of mafic lithologies, as has been previously suggested for the margin wedge [Ye et al., 1996; Christeson et al., 1999].

\subsubsection{Terrane Boundaries}

[52] In northern Costa Rica, within the region correlated to the Mesquito Terrane, $V p / V s$ is highly variable (see Figure 12) and thus it is difficult to correlate $V p / V s$ changes with terrane boundaries. An additional complication is that the Mesquito Terrane may be partly thrust-faulted over the Chorotega Block, as demonstrated by the large-scale nappe emplacement in the Santa Elena Peninsula [Geldmacher et al., 2008]. At Tortugal (Figure 13a) there are exposures of both the Nicoya Complex and alkaline basalts with no Galapagos signature similar to those in the Santa Elena Peninsula [Hauff et al., 2000]. The structural relationship between these exposures is not well known and may indicate that the basement is composed of both the CLIP and the Mesquito Terrane as proposed by Baumgartner et al. [2008]. In addition, magmatic processes may be modifying the crustal $V p / V s$, making it more difficult to identify terrane boundaries at surface.

[53] The traditionally accepted Chortis-Chorotega boundary interpreted along an east-west suture zone joining the Santa Elena and El Castillo peridotites with the Hess Escarpment [e.g., Dengo, 1985] (Figures 1 and 13a) is not visible from crustal $V p / V s$ estimates. In addition, serpentinized peridotites at the Tonjibe borehole [Astorga, 1992], in central Nicaragua [Baumgartner et al., 2008], and off the coast of El Salvador [Geldmacher et al., 2008] suggest that peridotites may be regionally widespread within the basement, as opposed to restricted to this narrow suture zone. Another possible Chortis-Chorotega boundary was inferred by MacKenzie et al. [2008] in southern Nicaragua (Figure 1) based on the transition in the crustal
$V p / V s$ between two stations in the back-arc region. However, this boundary would place the Mesquito Terrane exposures of El Castillo and Tonjibe as part of the Chorotega Block. We suggest that this $V p / V s$ transition may reflect a compositional change within the Mesquito Terrane.

[54] We favor the Chortis (Mesquito)-Chorotega boundary as the southwestward projection of the Hess Escarpment into central Costa Rica, as proposed by Baumgartner et al. [2008] (Figure 13a). This boundary does not conflict with geology and $V p / V s$ estimates. In general, $V p / V s$ is higher on the Chorotega side, although more $V p / V s$ data will be needed to determine if its location is visible from $V p / V s$ changes. We suggest that this boundary continues on the western margin of the Nicoya Gulf, separating the Mesquito and Nicoya Terranes (Figures 12 and 13) and following the boundary suggested by Hauff et al. [2000] who consider the Nicoya Peninsula as part of the Chorotega Block and both the Tortugal and Santa Elena areas as part of the Chortis Block (i.e., Mesquito Terrane).

\section{Conclusions}

[55] We identify the upper plate Moho (M2) as a relatively strong $V s$ contrast $(0.5-1.0 \mathrm{~km} / \mathrm{s})$ beneath the fore-arc, volcanic arc, and back-arc regions. In the Nicoya Peninsula, M2 was not recognized but instead we observe a signal that is consistent with a dipping interface which we interpret as the dipping oceanic Moho (M1) of the subducting Cocos Plate. The deepest M2 is observed in the volcanic arc region $(\sim 42 \mathrm{~km})$ and the shallowest M2 in parts of the fore arc $(27-33 \mathrm{~km}$, Papagayo Gulf region) and back arc $(29 \mathrm{~km}$, Costa Rica-Nicaragua border region). The strong azimuthal variation of the M2 Ps at JTS may reflect a complex M2 topography in the fore-arc region.

[56] Our receiver function observations are consistent with variability in the hydration state of the incoming Cocos Plate as was proposed in previous studies based on outer rise fault patterns, thermal state, and volcanic arc geochemistry [Rüpke et al., 2002; Fisher et al., 2003; Ranero et al., 2005]. We conclude that the observed Ps amplitude is consistent with a drier CNS1 oceanic mantle being subducted beneath the southernmost part of the Nicoya Peninsula, as compared to a serpentinized EPR oceanic mantle subducting beneath central and northern Nicoya. Our observations may imply that pervasive bending-related normal faulting in the EPR segment extends throughout the entire 
oceanic crust and facilitates the hydration of both the oceanic crust and upper mantle, as opposed to the CNS1, where hydration may occur more extensively only within the oceanic crust, resulting in a low-velocity layer that is visible beneath the southernmost part of the peninsula.

[57] By integrating our new receiver function estimates with published geological data and the receiver function estimates from MacKenzie et al. [2008], we describe, in terms of crustal $\mathrm{Vp} / \mathrm{Vs}$ estimates, three different crustal terranes: Mesquito, Nicoya, and Chorotega. The Mesquito Terrane shows variable $V p / V s$, suggesting mafic and ultramafic lithologies beneath the Costa RicaNicaragua border region, where $V p / V s$ estimates are high (1.82-1.88), and more silicic content in the Papagayo Gulf region and northern volcanic arc segment, where $V p / V S$ are moderate to low $(1.62-1.80)$ and resemble those of the continental crust. We conclude that the low to moderate $V p / V S$ in the fore arc and volcanic arc regions, together with the record of voluminous silicic magmatism, seismic velocities, and crustal thickness, may indicate that the midcrust and upper crust have been profoundly modified by emplacement of silicic melts. The Chorotega Block is characterized by high crustal $V p / V s(1.85-1.92)$ consistent with mafic lithologies constituting the CLIP. The Nicoya Peninsula is also a region of high crustal $\mathrm{Vp} / \mathrm{Vs}$ (1.80-1.87), which is consistent with mafic rocks, like those from the Nicoya Complex exposed at surface.

[58] Through a sensitivity study, we found that when dealing with a dipping interface, the $H$ and $\kappa$ calculations are biased toward shallower depths and higher $V p / V s$ estimates than true model parameters. Our synthetic tests indicate that the $H-\kappa$ stacking algorithm should be used with caution when the dip angle is known to be greater than $12^{\circ}$, as the bias in $V p / V s$ could be geologically significant, especially if the interface depth is greater than $35 \mathrm{~km}$. In addition, we found that the $H-\kappa$ stacking algorithm is not particularly sensitive to the assumed $V p$. We found that the $P s$ phase of receiver functions in the region along the strike of a dipping interface is very similar to a flat-interface case, and may be used when available to facilitate the interpretation of structures in regions with known dipping layers.

\section{Acknowledgments}

[59] A special thanks to S. Husen and V. Maurer for making data of the CORISUBMOD Experiment available and W. Taylor for assembling the Pocosol data set. Thanks to J. Calkins, A. Frassetto, I. Arroyo, and C. Gans for comments and helping with receiver function codes and two anonymous reviewers who significantly improved the manuscript. We used software written by C. Ammon and T. Owens and Matlab scripts initially created by H. Gilbert. Data from stations JTS, HDC, and CRSEIZE (in part) were obtained from the Data Management Center via the Incorporated Research Institutions for Seismology. Figures 1-3 and 11-13 were in part created with the Generic Mapping Tool by Wessel and Smith [1998]. Partial funding for this study was provided by NSF grants EAR0510966 (S. Beck and G. Zandt) and EAR0506463 (S. Schwartz).

\section{References}

Arroyo, I. G., S. Husen, E. R. Flueh, J. Gossler, E. Kissling, and G. E. Alvarado (2009), Three-dimensional $P$ wave velocity structure on the shallow part of the Central Costa Rican Pacific margin from local earthquake tomography using off- and onshore networks, Geophys. J. Int., 179(2), 827-849, doi:10.1111/j.1365-246X.2009.04342.x.

Astorga, A. (1992), Descubrimiento de corteza oceánica mesozoica en el Norte de Costa Rica y el Sur de Nicaragua, Rev. Geol. Am. Cent., 14, 109-112.

Barckhausen, U., C. R. Ranero, R. von Huene, S. C. Cande, and H. A. Roeser (2001), Revised tectonic boundaries in the Cocos Plate off Costa Rica: Implications for the segmentation of the convergent margin and for plate tectonic models, J. Geophys. Res., 106(B9), 19,207-19,220, doi:10.1029/ 2001JB000238.

Baumgartner, P. O., K. Flores, A. N. Bandini, F. Girault, and D. Cruz (2008), Upper Triassic to Cretaceous radiolaria from Nicaragua and northern Costa Rica-The Mesquito Composite Oceanic Terrane, Ofioliti, 33, 1-19.

Bullock, A. D., W. S. Holbrook, D. Lizarralde, H. van Avendonk, M. M. Mora, S. Harder, and G. Alvarado (2007), Results from the TICO-CAVA land seismic refraction survey, Eos Trans. $A G U, 88(52)$, Fall Meet. Suppl., Abstract T43C-08.

Carlson, R. L., and D. J. Miller (1997), A new assessment of the abundance of serpentinite in the oceanic crust, Geophys. Res. Lett., 24(4), 457-460, doi:10.1029/97GL00144.

Cassidy, J. F. (1992), Numerical experiments in broadband receiver function analysis, Bull. Seismol. Soc. Am., 82, $1453-1474$.

Christensen, N. I. (1996), Poisson's ratio and crustal seismology, J. Geophys. Res., 101(B2), 3139-3156, doi:10.1029/ 95JB03446.

Christensen, N. I. (2004), Serpentinites, peridotites, and seismology, Int. Geol. Rev., 46, 795-816, doi:10.2747/00206814.46.9.795.

Christeson, G. L., K. D. McIntosh, T. H. Shipley, E. R. Flueh, and H. Goedde (1999), Structure of the Costa Rica convergent margin, offshore Nicoya Peninsula, J. Geophys. Res., 104(B11), 25,443-25,468, doi:10.1029/1999JB900251.

DeMets, C., R. G. Gordon, D. F. Argus, and S. Stein (1994), Effect of recent revisions to the geomagnetic reversal time scale on estimates of current plate motions, Geophys. Res. Lett., 21(20), 2191-2194, doi:10.1029/94GL02118.

Dengo, G. (1985), Mid America: Tectonic setting for the Pacific margin from southern Mexico to northwestern Columbia, in The Ocean Basins and Margins, edited by A. E. Nairn and F. G. Stechli, pp. 123-180, Plenum, New York. 
Denyer, P., and E. Gazel (2009), The Costa Rican Jurassic to Miocene oceanic complexes: Origin, tectonics and relations, J. South Am. Earth Sci., 28(4), 429-442, doi:10.1016/ j.jsames.2009.04.010

Denyer, P., W. Montero, and G. Alvarado (2003), Atlas tectónico de Costa Rica, 81 pp., Ed. UCR, San José, Costa Rica.

DeShon, H. R., and S. Y. Schwartz (2004), Evidence for serpentinization of the forearc mantle wedge along the Nicoya Peninsula, Costa Rica, Geophys. Res. Lett., 31, L21611, doi:10.1029/2004GL021179.

DeShon, H., S. Y. Schwartz, A. V. Newman, V. González, M. Protti, L. M. Dorman, T. H. Dixon, D. E. Sampsom, and E. R. Flueh (2006), Seismogenic zone structure beneath the Nicoya Peninsula, Costa Rica, from three-dimensional local earthquake P- and S-wave tomography, Geophys. J. Int., 164, 109-124, doi:10.1111/j.1365-246X.2005.02809.x.

Di Marco, G., P. O. Baumgartner, and J. E. T. Channell (1995), Late Cretaceous-early Tertiary paleomagnetic data and a revised tectonostratigrapic subdivision of Costa Rica and western Panama, Spec. Pap. Geol. Soc. Am., 295, 1-27.

Drummond, M. S., M. Bordelon, J. Z. de Boer, M. J. Defant, H. Bellon, and M. D. Feigenson (1995), Igneous petrogenesis and tectonic setting of plutonic and volcanic rocks of the Cordillera de Talamanca, Costa Rica-Panama, Central American arc, Am. J. Sci., 295, 875-919.

Fisher, A. T., C. A. Stein, R. N. Harris, K. Wang, E. A. Silver, M. Pfender, M. Hutnak, A. Cherkaoui, R. Bodzin, and H. Villinger (2003), Abrupt thermal transition reveals hydrothermal boundary and role of seamounts within the Cocos Plate, Geophys. Res. Lett., 30(11), 1550, doi:10.1029/ 2002 GL016766.

Geldmacher, J., K. Hoernle, P. Van Den Bogaard, F. Hauff, and A. Klügel (2008), Age and Geochemistry of the Central American Forearc Basement (DSDP Leg 67 and 84), Insights into Mesozoic Arc Volcanism and Seamount Accretion on the Fringe of the Caribbean LIP, J. Petrol., 49(10), 1781-1815, doi:10.1093/petrology/egn046.

Grevemeyer, I., N. Kaul, J. L. Diaz-Naveas, H. W. Villinger, C. R. Ranero, and C. Reichert (2005), Heat flow and bending-related faulting at subduction trenches: Case studies offshore of Nicaragua and central Chile, Earth Planet. Sci. Lett., 236, 238-248, doi:10.1016/j.epsl.2005.04.048.

Grevemeyer, I., C. R. Ranero, E. R. Flueh, D. Kläschen, and J. Bialas (2007), Passive and active seismological study of bending-related faulting and mantle serpentinization at the middle America Trench, Earth Planet. Sci. Lett., 258, $528-$ 542, doi:10.1016/j.epsl.2007.04.013.

Hauff, F., K. Hoernle, P. van den Bogaard, G. Alvarado, and D. Garbe-Schönberg (2000), Age and geochemistry of basaltic complexes in western Costa Rica: Contributions to the geotectonic evolution of Central America, Geochem. Geophys. Geosyst., 1(5), 1009, doi:10.1029/1999GC000020.

Hayes, G., and K. P. Furlong (2007), Abrupt changes in crustal structure beneath the Coast Ranges of northern CaliforniaDeveloping new techniques in receiver function analysis, Geophys. J. Int., 170, 313-336, doi:10.1111/j.1365-246X. 2007.03401.x.

Hoernle, K., P. van den Bogaard, R. Werner, B. Lissinna, F. Hauff, G. Alvarado, and D. Garbe-Schönberg (2002), Missing history (16-71 Ma) of the Galápagos hotspot: Implications for the tectonic and biological evolution of the Americas, Geology, 30(9), 795-798, doi:10.1130/00917613(2002)030<0795:MHMOTG $>2.0$. CO 2 .

Horen, H., M. Zamora, and G. Dubuisson (1996), Seismic waves velocities and anisotropy in serpentinized peridotites from xigaze ophiolite: Abundance of serpentine in slow spreading ridge, Geophys. Res. Lett., 23(1), 9-12, doi:10.1029/95GL03594.

Husen, S., R. Quintero, E. Kissling, and B. Hacker (2003), Subduction-zone structure and magmatic processes beneath Costa Rica constrained by local earthquake tomography and petrological modeling, Geophys. J. Int., 155, 11-32, doi:10.1046/j.1365-246X.2003.01984.x.

Ivandic, M., I. Grevemeyer, A. Berhorst, E. R. Flueh, and K. McIntosh (2008), Impact of bending related faulting on the seismic properties of the incoming oceanic plate offshore of Nicaragua, J. Geophys. Res., 113, B05410, doi:10.1029/ 2007JB005291.

Kawakatsu, H., and S. Watada (2007), Seismic evidence for deep-water transportation in the mantle, Science, 316(5830), 1468-1471, doi:10.1126/science.1140855.

Langseth, M. G., and E. A. Silver (1996), The Nicoya Convergent Margin-A region of exceptionally low heat flow, Geophys. Res. Lett., 23(8), 891-894, doi:10.1029/ 96GL00733.

Langston, C. A. (1977), The effect of planar dipping structure on source and receiver responses for constant ray parameter, Bull. Seismol. Soc. Am., 67(4), 1029-1050.

Langston, C. A. (1979), Structure under Mount Rainier, Washington, inferred from teleseismic body waves, J. Geophys. Res., 84(B9), 4749-4762, doi:10.1029/JB084iB09p04749.

Ligoría, J. P., and C. J. Ammon (1999), Iterative deconvolution and receiver function estimation, Bull. Seismol. Soc. Am., 89, 1395-1400.

Lombardi, D., J. Braunmiller, E. Kissling, and D. Giardini (2008), Moho depth and Poisson's ratio in the westerncentral Alps from receiver functions, Geophys. J. Int. 173(1), 249-264, doi:10.1111/j.1365-246X.2007.03706.x.

MacKenzie, L., G. A. Abers, K. M. Fischer, E. M. Syracuse, J. M. Protti, V. Gonzalez, and W. Strauch (2008), Crustal structure along the southern Central American volcanic front, Geochem. Geophys. Geosyst., 9, Q08S09, doi:10.1029/ 2008GC001991.

Matumoto, T., M. Ohtake, and J. Umana (1977), Crustal structure in southern Central America, Bull. Seismol. Soc. Am., 67, 121-134.

Newman, A. V., S. Y. Schwartz, V. Gonzalez, H. R. DeShon, J. M. Protti, and L. M. Dorman (2002), Along-strike variability in the seismogenic zone below Nicoya Peninsula, Costa Rica, Geophys. Res. Lett., 29(20), 1977, doi:10.1029/2002GL015409.

Nikulin, A., V. Levin, and J. Park (2009), Receiver function study of the Cascadia megathrust: Evidence for localized serpentinization, Geochem. Geophys. Geosyst., 10, Q07004, doi:10.1029/2009GC002376.

Owens, T. J. (1984), Determination of crustal and upper mantle structure from analysis of broadband teleseismic $\mathrm{P}$ waveforms, Ph.D. thesis, 146 pp., Univ. of Utah, Salt Lake City.

Pizarro, D. (1993), Los pozos perforados en Costa Rica: Aspectos litológicos y bioestratigráficos, Rev. Geol. Am. Cent., 14, 81-85.

Protti, M., F. Güendel, and K. McNally (1994), The geometry of the Wadatti-Benioff zone under southern Central America and its tectonic significance: Results from a high resolution local seismograph network, Phys. Earth Planet. Inter., 84, 271-287, doi:10.1016/0031-9201(94)90046-9.

Quintero, R., and K. Kulhánek (1998), Pn-wave observations in Costa Rica, Geofis. Int., 37, 171-182.

Ranero, C. R., J. P. Morgan, K. McIntosh, and C. Reichert (2003), Bending-related faulting and mantle serpentinization at the Middle America trench, Nature, 425, 367-373, doi:10.1038/nature01961. 
Ranero, C. R., A. Villaseñor, J. Phipps Morgan, and W. Weinrebe (2005), Relationship between bend-faulting at trenches and intermediate-depth seismicity, Geochem. Geophys. Geosyst., 6, Q12002, doi:10.1029/2005GC000997.

Ranero, C. R., I. Grevemeyer, H. Sahling, U. Barckhausen, C. Hensen, K. Wallmann, W. Weinrebe, P. Vannucchi, R. von Huene, and K. McIntosh (2008), Hydrogeological system of erosional convergent margins and its influence on tectonics and interplate seismogenesis, Geochem. Geophys. Geosyst., 9, Q03S04, doi:10.1029/2007GC001679.

Rogers, R. D., P. Mann, and P. A. Emmet (2007), Tectonic terranes of the Chortis block based on integration of regional aeromagnetic and geologic data, Spec. Pap. Geol. Soc. Am., 428, 65-88, doi:10.1130/2007.2428(04).

Rossi, G., G. A. Abers, S. Rondenay, and D. H. Christensen (2006), Unusual mantle Poisson's ratio, subduction, and crustal structure in central Alaska, J. Geophys. Res., 111, B09311, doi:10.1029/2005JB003956.

Rudnick, R. L., and D. M. Fountain (1995), Nature and composition of the continental crust: A lower crustal perspective, Rev. Geophys., 33(3), 267-309, doi:10.1029/95RG01302.

Rüpke, L. H., J. P. Morgan, M. Hort, and J. A. D. Connolly (2002), Are the regional variations in Central American arc lavas due to differing basaltic versus peridotitic slab sources of fluids?, Geology, 30(11), 1035-1038, doi:10.1130/00917613(2002)030<1035:ATRVIC $>2.0 . C O ; 2$.

Sallarès, V., J. J. Dañobeitia, E. Flueh, and G. Leandro (1999), Seismic velocity structure across the Middle America land bridge in northern Costa Rica, J. Geodyn., 27, 327-344, doi:10.1016/S0264-3707(98)00007-6.

Sallarès, V., J. J. Dañobeitia, and E. Flueh (2000), Seismic tomography with local earthquakes in Costa Rica, Tectonophysics, 329, 61-78, doi:10.1016/S0040-1951(00)00188-8.

Sallarès, V., J. J. Dañobeitia, and E. R. Flueh (2001), Lithospheric structure of the Costa Rican Isthmus: Effects of subduction zone magmatism on an oceanic plateau, J. Geophys. Res., 106(B1), 621-643, doi:10.1029/2000JB900245.

Sinton, C. W., R. A. Duncan, M. Storey, J. Lewis, and J. J. Estrada (1998), An oceanic flood basalt province within the Caribbean Plate, Earth Planet. Sci. Lett., 155, 221-235, doi:10.1016/S0012-821X(97)00214-8.
Stein, C. A., and S. Stein (1992), A model for the global variation in oceanic depth and heat flow with lithospheric age, Nature, 359, 123, doi:10.1038/359123a0.

Syracuse, E. M., G. A. Abers, K. Fischer, L. MacKenzie, C. Rychert, M. Protti, V. González, and W. Strauch (2008), Seismic tomography and earthquake locations in the Nicaraguan and Costa Rican upper mantle, Geochem. Geophys. Geosyst., 9, Q07S08, doi:10.1029/2008GC001963.

Vogel, T. A., L. C. Patino, G. E. Alvarado, and P. B. Gans (2004), Silicic ignimbrites within the Costa Rican volcanic front: Evidence for the formation of continental crust, Earth Planet. Sci. Lett., 226, 149-159, doi:10.1016/j.epsl.2004. 07.013.

Vogel, T. A., L. C. Patino, J. K. Eaton, J. W. Valley, W. I. Rose, G. E. Alvarado, and E. L. Viray (2006), Origin of silicic magmas along the Central American volcanic front: Genetic relationship to mafic melts, J. Volcanol. Geotherm. Res., 156, 217-228, doi:10.1016/j.jvolgeores.2006.03.002.

von Huene, R., C. R. Ranero, W. Weinrebe, and K. Hinz (2000), Quaternary convergent margin tectonics of Costa Rica, segmentation of the Cocos Plate, and Central American volcanism, Tectonics, 19(2), 314-334, doi:10.1029/ 1999TC001143.

Wessel, P., and W. H. F. Smith (1998), New improved version of the generic mapping tools released, Eos Trans. AGU, 79, 579, doi:10.1029/98EO00426.

Ye, S., J. Bialas, E. R. Flueh, A. Stavenhagen, R. von Huene, G. Leandro, and K. Hinz (1996), Crustal structure of the Middle American Trench off Costa Rica from wide-angle seismic data, Tectonics, 15(5), 1006-1021, doi:10.1029/ 96TC00827.

Zandt, G., and C. J. Ammon (1995), Continental crust composition constrained by measurements of crustal Poisson's ratio, Nature, 374, 152-154, doi:10.1038/374152a0.

Zandt, G., H. Gilbert, T. J. Owens, M. Ducea, J. Saleeby, and C. H. Jones (2004), Active foundering of a continental arc root beneath the southern Sierra Nevada in California, Nature, 431, 41-46, doi:10.1038/nature02847.

Zhu, L., and H. Kanamori (2000), Moho depth variation in southern California from teleseismic receiver functions, J. Geophys. Res., 105(B2), 2969-2980, doi:10.1029/ 1999JB900322. 